\title{
Kyara in Japanese Religious Spaces
}

\author{
Alisha Saikia \\ (iD) https://orcid.org/0000-0002-0028-8003
}

\begin{abstract}
Mascots in Japan are called kyara. They are utilised by almost all organisations, institutions, and administrative divisions and are accepted, embraced, and consumed by people of all walks of life, making them immensely popular. Although constituting an element of Japanese popular culture, they are also embedded in certain religious spaces in Japan, making them an interesting topic of research. This article will examine the reason behind the embeddedness of kyara in certain religious spaces in Japan and their impact on the practice of religion in those spaces.
\end{abstract}

Keywords: kyara, Japanese popular culture, religion, shūkyō asobi

Saikia, Alisha. 2021. “Kyara in Japanese Religious Spaces.” Vienna Journal of East Asian Studies, 13, pp. 257-297.

https://doi.org/10.2478/vjeas-2021-0008

Submitted: 05.01.2021, accepted: 19.05.2021 


\section{Introduction}

The ubiquitous presence of anthropomorphic characters or kyara キャラ (mascots) in Japan is a bewildering phenomenon. It would not be an exaggeration to say that Japan is a land of kyara. From the global icon Hello Kitty ハローキティ, being the ambassador of tourism in Japan, the national craze Kumamon くまモン with 300,000 followers and a billion-yen industry around it, to anonymous smiling characters handing over pamphlets to people who walk on the streets of Japan, kyara are performing several roles and seem to be omnipresent in Japan. They are used by almost every institution and organisation imaginable in Japan and are accepted, embraced, and consumed by people of all generations and walks of life. Kyara are predominant in every prefecture, post office, police station, fire department, subway stations, train lines, political parties, courts, shrines, temples, and even prisons to name a few. It is a multi-billiondollar industry and with a new kyara appearing almost every day, their popularity seems to be thriving.

One of the most interesting aspects of kyara is their increasing use in certain religious spaces in Japan. Kyara have started appearing in religious products such as omamori お守り (protective amulet) or ema 絵馬 (votive tablet), and shrines and temples have begun appropriating them as their mascots or started creating new kyara images as contemporary personas of old gods. Some shrines and temples such as Naritasan Shinshoji 成田山新勝寺 in Narita 成田市, or Kinkakuji 金閣寺 (Golden Pavilion) and Nishiki Tenmangu 錦天満宮 in Kyōto 京都 have their omamori with the images of popular San-X and Sanrio (Japanese companies) characters, like Rilakkuma リラックマ and Hello Kitty. A small shrine named Kyōtodai 京都大 in Kyōto has created a moe kyara 萌えキャラ called Miko Tan みこたん as their official mascot who also functions as their shrine maiden. The city of Ashikaga 足利市 in Tochigi prefecture 栃木県 created two kyara called Hime 姫 and Tama たま, their full names being Hatagami Orihime はたがみ織姫 and Kadota Mitama 門田みたま and representing the two deities enshrined in the Ashikaga Orihime Jinja 足利織姫神社 and the Kadota Inari Jinja 門田稲荷神社. The deities are linked with en-musubi 縁むすび (love-ties) and en-kiri 縁切り (cutting ties especially from negativity) (Porcu 2013). In Hachiōji 八王子市, Tōkyō, the Nichirenist temple Shoiezan Ryōhōji 松栄山了法 寺 has created a moe 萌え-patterned kyara of its enshrined deity Benzaiten 弁才天 and renamed it to Toro-Benten とろ弁天; ${ }^{1}$ the very popular shrine of Kanda 神田, Tōkyō, called Kanda Myōjin 神田明神, has adopted the anime kyara Nozomi Tojo 東條希 as its official idol; and Ishiura Jinja 石浦神社 in Kanazawa 金沢, Ishikawa

\footnotetext{
${ }^{1}$ Benzaiten is a Japanese deity commonly associated with that of wealth. She is a Japanese manifestation of the Indian Goddess of music and knowledge called Sarasvatī., Sarasvatī who is always portrayed playing a vin̄a (zither), and whereas Benzaiten is shown playing a biwa 琵琶 (lute).
} 
prefecture 石川県, has an adorable yuru kyara ゆるキャラ called Kima Chan キマち やん.

Some shrines benefit from the growing otaku おたく pilgrimage. ${ }^{2}$ Sometimes certain shrines get featured in an anime and/or manga and - although the shrines themselves do not adopt any anime kyara from these anime and manga series - they get frequently visited by legions of anime fans, thus making these shrines very popular. These fans then draw the pictures of their favourite character on the ema (votive tablet/wooden wishing plaques) and leave it in the shrine premises with their wishes written on them. Some examples of these kinds of shrines are: Washinomiya Jinja 熟宮 神社 in Kuki 久喜市, Saitama prefecture 埼玉県, which got featured in the anime Lucky Star らきすた, where the protagonists of the anime were the shrine maidens; Oarai Isosaki Jinja 大洗磯前神社 shrine in Oarai 大洗市, Ibaraki prefecture 茨城県, popular for being featured in the famous anime Girls Und Panzer ガールズ\&パンツ ア一; Hikawa Jinja 水川神社 in Akasaka 赤坂, Tōkyō, for being featured in the immensely popular anime Sailor Moon 美少女戦士セーラームーン; Omi Jingu 近江神 宮 in Otsu 大津市, Shiga prefecture 滋賀県, which was shown in the anime Chiyafuru チヤフル. This phenomenon has made such shrines immensely popular. For example, visits to the Washinomiya Jinja increased from 90,000 to 300,000 yearly visitors in 2008 after being featured in the anime Lucky Star. The numbers continued to increase to 420,000 in 2009 and to 450,000 in 2010 (Porcu 2013: 287).

Whereas kyara are embedded in certain religious spaces in Japan, some kyara also utilise religious motifs and symbols in their design and aesthetic. For example, some are designed based on particular engimono 縁起物 and yōkai 妖怪 (a mysterious creature, a monster or fantastic being, a sprite or spirit), and some use other religious motifs in their design aesthetic, like parts of a shrine or a purification rope (shimenawa 注連縄) ${ }^{3}$

\footnotetext{
${ }^{2}$ According to Okamoto (2015), otaku refers to a predominantly male demographic who is devoted to a bunch of popular culture phenomena intrinsically related to manga, anime, and computer games. Otaku pilgrimage is the visit of these avid fans to the places where their favourite and beloved anime, manga, or computer game is based on. Since these locations are being flocked by hordes of devoted otaku, these persons are called otaku pilgrims and these sites are termed "anime pilgrimage or sacred sites." However, the term "pilgrimage" for such fan visits to shrines is highly debatable.

${ }^{3}$ Engimono are things that assist in bringing about a good engi 縁起. The historical origins and wondrous tales of the temples and shrines in Japan are known as engi. However, the term is originally derived from the core teachings of Buddhism. Engi is the contraction of a Buddhist concept called inen seigi. In refers to the direct causes and en refers to the indirect ones. This Buddhist concept highlights the agency of the individual in deterring his/her destiny. It is in the category of indirect causes (en) where divine support belongs. En which literally means "bond" or "thread" refers to the relationship between deities and humans with the help of which people try to influence their fate. Another meaning of the term engi is the miraculous signs that could foretell if some proposed task is good or evil. Based on this meaning, engi ga ii 縁起がいい (omens presaging good fortune) or engi wo katsugu 縁起を担ぐ (to believe in superstitious omens) came into existence, and
} 
Hence, certain religious spaces using secular popular culture products, and the presence of religious elements in such products raise certain questions, such as: Why are kyara being used in some religious spaces in Japan? How does the use of kyara impact the practice of religion in those spaces? This article is an attempt to find certain suitable answers to these questions. To arrive at these answers, extensive fieldwork was conducted in Kanda Myōjin in Kanda, Tōkyō, Ryōhōji in Hachiōji, Tōkyō, and Ishiura Jinja in Kanazawa, Ishikawa prefecture.

Regarding the question of why a popular culture element like kyara is used in certain religious spaces in Japan, some scholars indicate consumerism, globalisation, and secularisation as the reasons for such merger. This explanation, however, overlooks another very important factor of a long existing tradition in Japanese religion, where the secular elements of play and entertainment are enmeshed with the "sacred" elements of religion, therefore decreasing the distinction between the two. This feature highlights the fact that religious spaces utilise secular aspects of play and entertainment as a continuation of a tradition from the Edo era by routinely refurbishing it. This insertion of secular elements in religious spaces cannot just be viewed as frantic measures to combat with the pressures of consumerism and secularisation in a contemporary society.

In regard to the question of what impact does the instillation of kyara in these spaces have on the practice of religion, it can be said that it leads to a recreation and reinvention of religion, with religion being an expression of both the sacral and the play. The practice of religion in this way denies the claims of a secularisation theory that argues about the shrinking role of religion in a contemporary society.

In the next section the idea of kyara in Japan is explained followed by a discussion on the academic commentary on kyara by different scholars. In the sections Kyara in Kanda Myōjin, Ryōhōji, and Ishiura Jinja, a brief history of these temples and shrines as well as a detailed description of what kind of kyara are introduced in these spaces is offered. Subsequently, the reason behind this embeddedness is explained in detail

the custom of celebrating a good omen (engi iwai 縁起祝い) or “changing one's luck” (engi naoshi 縁起直し) spread extensively. It is from here that the term engimono sprung. Any good luck charm purchased in the beginning of the year or on the "feast day" of a Buddhist deity started to be called engimono. The term initially referred to just shimenawa (rice straw or hemp rope for ritual purification) and kadomatsu 門松 (pine and bamboo gateway decoration). But later several different things were subsumed under the term engimono. It is believed that these engimono, if placed in the engidana 縁棚 (good-luck altar) at home, would bring luck and prosperity, and the benevolence of the kami and Buddha will blossom. Instead of a separate engidana, engimonos are generally placed in the kamidana 神棚, which is a small Shinto altar where the protective deities of the house are displayed and worshipped. Examples of engimono are “treasure ships” (takarabune 宝船), “fortunebeckoning cats” (manekineko 招き猫), daruma 達磨 dolls, good-luck bulls, rice scoops, chigi bako ちぎばこ (small wooden boxes sold at the shrine Shiba Daijingu 芝大神宮, and representing hopes for an increase in the number of kimono one owns), and others (Daniels 2003). 
in the sections "Market Spaces with Religious Connotation," "Religion, Play and Entertainment," and "Entertainment and Shintō Matsuri." Finally, the impact of incorporating kyara in religious spaces is discussed.

\section{Defining Kyara}

Mascot characters in Japan are called kyarakuta キャラクター or kyara. According to Kuresawa (2010), a kyara is an all-pervasive fictitious performed personality with a sense of exuberance that performs a variety of functions in the fictitious role it holds. Itō Gō 伊藤剛 (2000) made a distinction between kyarakuta and kyara. In his view, the former have content and possess a personality which is firmly supported by a narrative (e.g., Tezuka's Astro Boy). ${ }^{4}$ The latter, in contrast, are devoid of any narrative and are created purely as an icon, therefore can be used in multiple ways and attached to any object. Example of this could be a number of food, instructional, or warning characters created merely with a cute (kawaii かわいい) design aesthetic but without a backstory. However, this sharp distinction does not hold true because kyara are increasingly understood as an all-encompassing term for different kinds of characters and not just as characters without a narrative. Through this definition, kyara can be a broad category of commercial characters like Hello Kitty (the fiercely popular cat character from Sanrio) and Rilakkuma リラックマ (bear character from San-X), characters of manga and anime like Pokémon ポケモン (pocket monsters), Doraemon ドラえ もん (robotic cat), Anpanman アンパンマン(bean-paste bread man), and persons that wear fuzzy costumes and become kigurumi 着ぐるみ (costumed characters) and perform the role of a mascot. They are called imegi kyara イメージキャラ (image characters) (Occhi 2012). These imegi kyara were later called yuru kyara.

Yuru kyara is a subcategory of kyara. It is a combination of two words: yuru, which means loose, and kyara, which is an abbreviated form of kyarakuta (character). It is also sometimes written as yuru chara ゆるキャラ. In the early 2000 s, the illustrator and cultural critic Miura Jun みうらじゅん (b. 1958) coined the term yuru kyara for the local mascots that represented distinctive products and features of a locality and were initially called imegi kyara. Miura also defined and specified what these characters are:

Characters designed for PR of local governing bodies, events, and local goods, especially when in kigurumi form. They have the Japanese trait of fansh $\overline{~[フ ァ ン シ ー] ~ a n d ~ a t ~ f i r s t ~ g l a n c e ~ o n e ~ c a n ~}$

\footnotetext{
${ }^{4}$ Tezuka Osamu 手塚治虫 (1928-1989) was an eminent manga artist known as the "God of Japanese comics." He played a pivotal role in the development of postwar manga. "Astro Boy" was one of the most successful manga written and illustrated by him. It is a science fiction which revolves around a futuristic society where both humans and robots coexist, with the protagonist being a highly developed android called “Astro Boy” (MacWilliams 2014).
} 
understand the strong message they communicate about a local specialty or characteristic. There are also characters that need explanation for one to know what on earth they are. While bearing originality, when they are made into kigurumi they often have a sense of instability that makes them more lovable, and one's heart feels healed [iyasarete 癒されて] just by looking at them (translation drawn from Occhi 2012).

When Miura coined the term, he also created the criteria for what is qualified as a yuru kyara. Officially, it must have three characteristics: (1) it must convey a strong message of love for one's hometown; (2) the character's movements or behaviours should be unique and unstable or awkward; (3) the character should be unsophisticated or laid-back and lovable (Miura 2009).

Since then, the term has been widely used by the Japanese populace and the media to refer to local mascots. However, since it has been patented by Miura as a registered trademark of the company Yuru kyara K.K., another term called gotouchi kyara ご当 地キャラ is being used to refer to these local mascots to prevent any legal hassles.

Moe kyara 萌えキャラ is yet another category of kyara. These are characters that have a mixture of "moe" and "yuru" characteristics (defined above by Miura). Galbraith (2009) defines what these characteristics are: "moe characteristics: large, pupilless eyes, glossy skin, small (or no) breasts and an innocent or pure personality." It is a sexualised image of a fantasy character. The word moe first appeared in the 1990s in the bulletin board website "2channel," in the forum where the discussion about the passionate desire about anime girls who are infantile, innocent, and sweet took place. The word entered the common vocabulary after the popularity of an otaku, Densha Otoko's 電車男 story, in which he saved a girl from a drunkard in a train, and later, with recommendations from his fellows on "2channel," successfully dated her. This story was created as a collaborative effort on the board for single men in "2channel," and between March and May 2004 it became an internet book, a film, a prime-time television show, four manga series, and an erotic video. The last episode of the drama was aired during prime time on Fuji TV and was viewed by 25.5 per cent of the national audience. The catchphrase by the protagonist 'moeeeee!' became a media sensation (Galbraith 2009).

The history of moe kyara goes back to the immensely popular TV anime Neon Genesis Evangelion 新世紀エヴァンゲリオン (1995-1996) by Gainax ガイナックス. The anime featured a hugely popular female character who was a synthesis of different characters, called Ayanami Rei 綾波レイ. After her success, kyara with moe traits came into existence. One of the main examples is Dejiko でじこ or Di Gi Charat デ・ ジ・キャラット, a cute little cat girl who became the mascot for anime merchandiser Gamer's in 1998. She does not have a backstory but possesses moe characteristics, such as a maid costume, cat ears (nekomimi 猫耳), giant eyes, screechy voice, and so on. Characters like Dejiko, whose main purpose is to produce affect, are called moe kyara (Azuma 2009). Moe kyara are not as proliferated as yuru kyara and are still a very new category of kyara. 
Therefore, mascot characters in Japan are called kyara, with yuru kyara, and moe kyara being subcategories. Even characters that are not indigenous to Japan but have achieved a great rate of success and popularity in the country are also grouped under the popular term kyara or kyarakuta. For example, Snoopy (character from Charlie Brown's popular comic strip "Peanuts"), Disney characters like Mickey Mouse, Peter Rabbit (character from Beatrix Potter's popular children's book Peter Rabbit), the Moomin trolls (characters from Finnish author Tove Jannson's famous series Moomin), and so on.

For this article, Occhi's (2012) aforementioned definition of kyara will be utilised, according to which kyara is an all-inclusive term for commercial kyara, anime kyara, yuru kyara, and moe kyara.

\section{The Study of Kyara}

Scholarly work concerning kyara has mostly been done from the perspective of their functionality and rationale behind their consumption. This section is a brief overview of such works. Birkett (2012) talks about the functionality of kyara as a means to revitalise certain dying towns and cities of Japan, wherein the childlike potential of the kyara helps the residents to connect to them. Barrows (2014) extensively discusses the functionality of gotouchi kyara as a massively successful tool that has been used for city branding. Occhi (2012) describes these kyara as local heroes with a purpose whose relatability with their audience also acts as an effective means to communicate moral and civil messages. Kyara have also been perceived by scholars as products for enhancing Japan's soft power. McGray (2002) views them as an endeavour by Japan to reinvent itself as a cultural superpower, and Iwabuchi (2008) sees such a movement as a form of cultural imperialism with Japan's massive popular cultural flows to East and Southeast Asia.

Some scholars also point out the fact that certain kyara are used by government organisations and other agencies in order to soften their stringent image. McVeigh (2000) argues that kyara are used to moderate certain strict, controversial, or troublesome images and issues. For example, the kyara of the Japan Self Defence Forces are the cute looking Prince Pickles (Pikurusu ピクルス) and Little Parsley (Paseri Chan パセリちゃん). Similarly, a mouse-like creature called Pipo kun ピーポくん is the kyara for the Tōkyō Metropolitan Police Department, who is also seen doing jobs like handing out pamphlets to pedestrians and warning about molesters (chikan 痴漢) in the Tōkyō train stations.

According to Miyake (2001), the Japanese government endeavours to domesticate nuclear related issues although Japan is a country of high seismic risk and has already faced the mishap of the Fukushima Daiichi Nuclear Disaster. The Japanese Atomic Energy Agency has kyara such as Pluto Kun プルトくん, Uran Boyu ウラン ボユ, and 
Natrium Chan ナトリウムちゃん, who talk about the benefits of nuclear energy and help in promoting a positive image.

According to some scholars, even the design aesthetics of some kyara make them hugely successful over others and lead to their mass consumption. Belson and Bremner (2003) talk about the global popularity of Hello Kitty, who can easily travel from one culture to another and express different things to different groups of people because of its simple design without a mouth, which enables the consumers to reflect their own feelings through this kyara. McVeigh (2000) iterates the same point. Stevens (2014) puts forward the argument that since most of the kyara have an extensive narrative behind them, it helps in strengthening the consumers' interaction with the characters, which in turn accelerates their consumption.

According to Jillian Rae Sutera (2016), an additional reason for such massive consumption of these kyara could be the idea of creating an identity for the consumers themselves. Since Paul Bloom in his work How Pleasure Works (2010) identified how buying a brand is a process of creating one's identity, Sutera (2016) maintains that buying kyara and other "Cool Japan"-related merchandise makes the consumers identify themselves with the brand of "Cool Japan."

Despite various scholars' work on the different functionalities of kyara and the motivation behind their consumption, academic commentary around the use of kyara/mascots in religious spaces has been largely overlooked. Porcu (2014) talks about the case of the Nichiren Buddhist temple Ryōhōji in Hachiōji, Tōkyō, where the statue of Benzaiten is converted into a moe kyara as a branding strategy to reinvigorate the temple's dying membership. According to Porcu, Japan's rising consumerism, secularism, and globalisation is what has led this temple to immerse in and intermingle with popular culture to keep itself alive and thriving. She also touches upon the use of the image of Hello Kitty on the omamori of the two Zen temples of the Rinzai sect, called Kinkakuji (Golden Pavilion) and Ginkakuji 銀閣寺 (Silver Pavilion), and uses the same argument of consumerism and globalisation to discuss this occurrence. Porcu (2013) also utilises the same perspective of the constraints of consumerism and religious institutions' dire need to use branding strategies in a consumerist society governed by market logics to study the case of the creation of the two moe kyaras Hime and Tama in the city of Ashikaga in Tochigi prefecture, as well as the Washinomiya Jinja, famous for being featured in the Lucky Star anime. Although an important perspective, this standpoint can be restrictive if taken by and of itself. The idea of the conflation between play, entertainment, and religion, which is an integral part of Japanese religious tradition, must be investigated while also taking into account the usage of kyara in religious spaces and its continuities from the past. 


\section{Kyara in Kanda Myōjin}

The history of Kanda Myōjin dates to the Nara period 奈良時代 and the year 730, when a shrine called Kanda no Miya 神田/宮 was established in a Japanese village in Mushashi Province 武蔵国. The shrine maintains it was founded by and named after Makanda Omi 神田臣, who was a descendant of the hereditary clan of priests (jingi shizoku 神祇士族) of Izumo 出雲. However, there is another belief that Kanda 神田 (land of Gods) refers to the position of an area that once belonged to Ise Jingu 伊勢神宮. In the beginning of the Edo Period 江戸時代 (1603-1868), the Edo castle went through an expansion programme and the shrine was relocated in the Kanda region. In 1616, the shrine got further relocated to its current site on a small hill in Akihabara 秋葉原. Throughout the course of its history, the shrine was restored and reconstructed several times. However, after the Great Kantō Earthquake of 1923, the shrine was finally reconstructed as an earthquake and fireproof building and completed its construction on May 6, 1933 (Cali and Dougill 2012). There are three deities enshrined there, namely Daikokuten 大黒天, Ebisu 恵比須, and Taira no Masakado 平将門. These deities are believed to be the guardians of the 108 neighbourhoods of Tōkyō, including the Akihabara, Kanda, Nihombashi 日本橋, Marunochi 丸の内, and Tsukiji 築地 areas. Popular in Shintō mythology as the kami of land and industry, Daikokuten 大黒天 is the deity of marriage. Daikoukuten is supposed to have originated from the Hindu warrior deity Mahākāla who is an emanation of the Hindu God Siva (the destroyer from the supreme trinity in Hinduism), or an incarnation of Daijizaiten 大自在天 (Japanese name for Hindu God Siva) also known as the God of war. Ebisu originated from Shintō mythology and is the patron deity of fishermen. He also helps in the development of land, industry, and medicine. Both these deities are part of the popular entourage of Shichifukujin 七福神 (Seven Lucky Gods). ${ }^{5}$

The other deity, Taira no Masakado (d. 940), was a samurai in the Heian period 平 安時代 (794-1185). He led a huge rebellion against the Heian court of Emperor Suzaku 朱雀天皇 (921-952; r. 930-946) in 939. He was killed in the rebellion and his severed head was brought back to Kyōto, but it somehow found its way to the fishing village of Shibasaki 芝崎村一the present-day Otemachi 大手町 area of Tōkyō where the original Kanda shrine was located. It was buried there, and a memorial stone was built. In 1309, Taira no Masakado was enshrined in Kanda to appease his angry spirit

\footnotetext{
${ }^{5}$ The Shichifukujin are the gods of fortune in Japan. They are the benefactor gods of different arts, skills, and professions. They originate from India, China, and indigenous Japanese beliefs. They are: Ebisu, Benzaiten, Daikokuten, Bishamonten 毘沙門天, Hotei 布袋, Jurōjin 寿老人, and Fukurokuju 福禄寿 (Chiba 2012).
} 
when a plague hit Kanda and the cause was attributed to his enraged spirit. The accounts of his bravery are popular throughout Japan, leading to awe and reverence towards him and elevating his status to a kami (Cali and Dougill 2012).

Kanda Matsuri 神田祭 is an important aspect of Kanda Myōjin's popularity. It is held in mid-May of every odd year. It is not only one of the biggest festivals in Tōkyō but also one of the biggest festivals held in Japan. Another name of the festival is Tenka Matsuri 天下まつり. The celebration of the festival dates to the beginning of the Tokugawa Shogunate 徳川幕府 after the victory of Tokugawa Ieyasu 徳川家康 (1543-1616) at the Battle of Sekigahara 関ヶ原の戦い. The festival started to mark the prosperity and exorbitance of the Edo period and continues to be celebrated with much pomp and show till today. Its main feature is the grand procession throughout Kanda and Nihonbashi 日本橋 districts with people carrying a beautiful omikoshi お 神輿 (portable shrine).

In 2010, a popular anime series called Love Live ラブライブ began in Dengeki 電 撃 G's Magazine. It is the story of nine high school girls who set up a pop idol band to save their school from closing down. One of the main characters is a girl called Nozomi Tojo, who is a shrine maiden in Kanda Myōjin. These group of girls are often seen to gather in the shrine and hang out in the steep stairs leading to the temple (Myōjin Otokozaka 明神男坂 slope). They also engage in an exercise routine of running up and down the stairs as part of training to become idols.

Since the shrine got featured in this famous anime series, Kanda Myōjin collaborated with the Love Live anime in November 2014 and began to produce ema (votive wooden tablets) with all the Love Live characters dressed as shrine maidens. This attracted a lot of fans (lovelivers, as they like to call themselves) to the shrine, leading to a massive sale of the ema. The shrine then started producing omamori with Love Live characters on it. The omamori were also met with a similar response. Soon the shrine began producing other merchandise products, like mobile trinkets, posters, mugs, folders, diaries, etc. and established a Love Live merchandise shop within the precinct of the shrine on January 1, 2015. In May 2015, during the Kanda Matsuri, there were posters of the Love Live characters dressed as shrine maidens that attracted a huge number of fans to the festival. ${ }^{6}$

\footnotetext{
${ }^{6}$ Information collected on September 13, 2017, from an interview with Kishikawa Masanori, who is a junior priest (gonnegi 権禰宜) at Kanda Myōjin.
} 


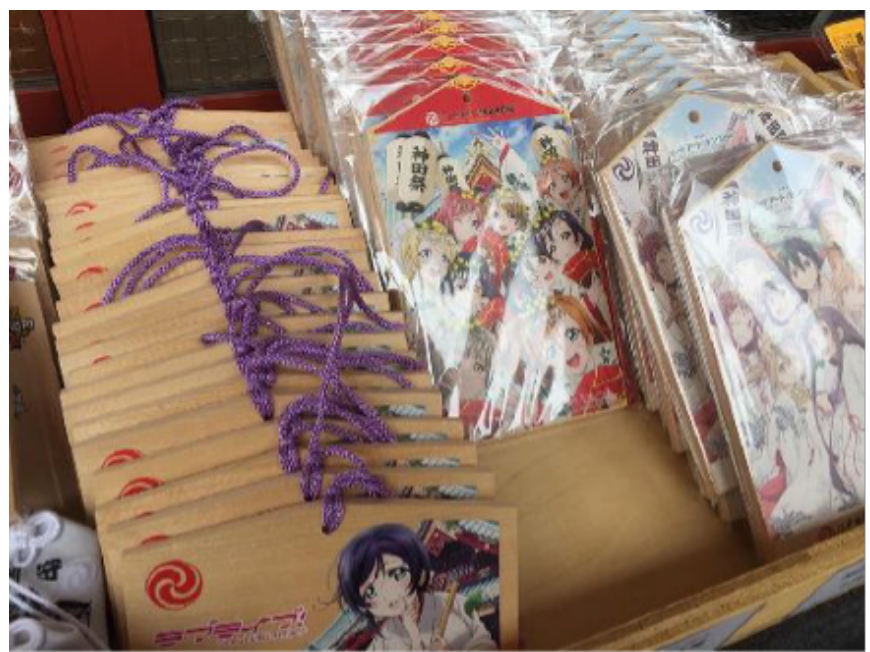

Figure 1: Ema with the image of Nozomi Tojo from Love Live in Kanda Myōjin, Tōkyō. Photo taken by the author.

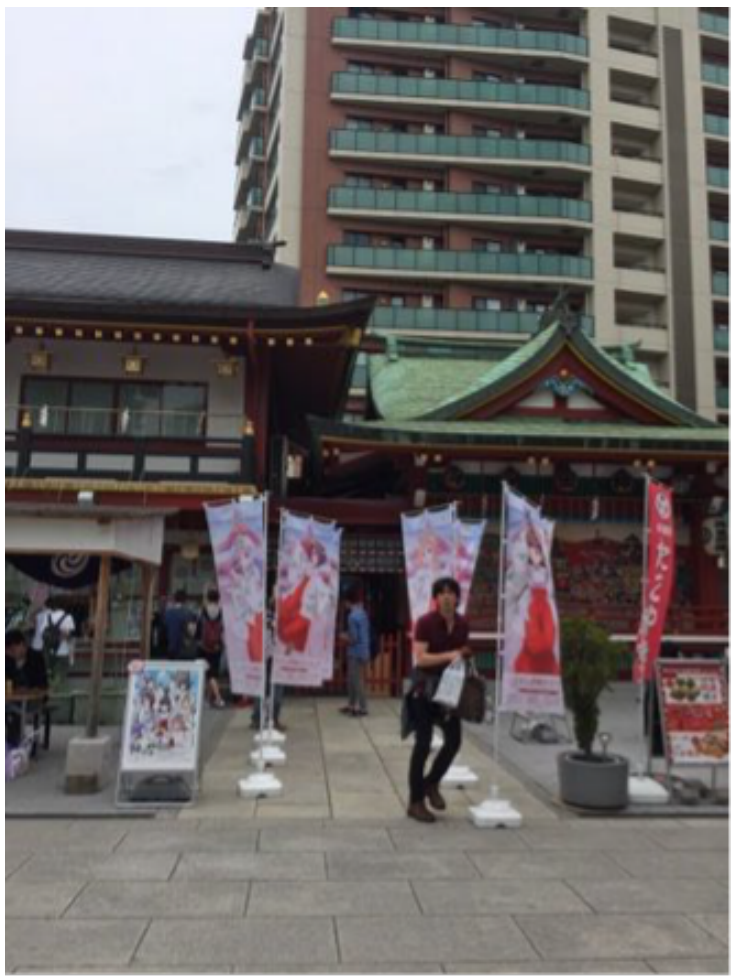

Figure 2: Love Live merchandise shop in Kanda Myōjin, Tōkyō. Photo taken by the author. 
The increasing number of shrine visitors that included anime lovers and lovelivers encouraged Kanda Myōjin to continue its collaboration with the anime and continued to thrive. In 2015, Kanda Myōjin announced on its twitter page that they adopted Nozomi Tojo as the official idol for the shrine.

However, Kanda Myōjin's collaboration with the anime Love Live was not a sudden development. Being at the centre of the anime/manga haven Akihabara in Tōkyō, the shrine started collaborating with various manga/anime for several years, since both the shrine and the artist or the company that produces them benefits from it.

An interview with Kishikawa Masanori, a junior priest and spokesperson of the shrine, was conducted on September 13, 2017. He is a doctoral student whose thesis examines the historical development and transition of the Kanda festival in the modern times. He mentioned that several anime such as Keroro Gunso ケ口ロ軍曹 and Inuyasha 犬夜叉 also collaborated with the shrine before Love Live, especially during Kanda Matsuri. However, later on, during online communication, he said that there is no special reason behind the collaboration with only these specific anime/manga. The reasons were either friendly relations with the artist/company or the artist/company would benefit from being displayed in a large platform such as the Kanda Matsuri, leading to the shrine garnering more popularity and adding further entertainment elements to the festival. Also, since the shrine is located at the centre of Akihabara, collaborating with anime/manga seemed like a sensible approach for creating additional amusement for the festival. However, in the case of Love Live the reason was different, given that since the Kanda shrine got featured in the anime it led to the establishment of a special relationship with the shrine.

Kishikawa also mentioned that even before collaborating with anime and manga series, Kanda Myōjin has always been a space for both the preservation of traditional elements of religious significance and the introduction of new entertaining elements given the changing times. He talked about several memorials that can be found in the shrine complex, and especially mentioned the Zenigata Heiji 銭形平次 Memorial in honour of Zenigata Heiji found inside the Kanda Myōjin precinct. Created by Kodo Nomura 野村胡堂 (1882-1963) in 1937 and set in the Edo period, Zenigata Heiji is a popular fictional character of a policeman who arrests criminals by throwing coins at them. Several novels have been written and TV shows and films have been made based on this character. His popular hangout place was Kanda Myōjin and he called himself myōjinshita no heiji 明神下の平次 because he lived in a terrace house below Kanda Myōjin (Schreiber 2000).

Apart from this memorial stone there exist several others dedicated to haiku poets like Tsunoda Chikurei 角田竹冷 (1857-1919), and ukiyo-e 浮世絵 painters like Mizuno Toshikata 水野年方 (1866-1908). The shrine complex also has a museum displaying ukiyo-e paintings.

Kanda Myōjin also has a special IT omamori that can be used to protect gadgets like laptops, computers, and iPads. Located in the Akihabara, which is also called 
electric town because of its wide selection of electronics and technology, the shrine felt the need to produce an IT omamori that could protect gadgets against viruses.

In his interview Masanori further added that Kanda Myōjin is a shrine where traditional and cultural elements are preserved, while simultaneously keep on procuring new elements to create new culture. It is in a state of constant flux and renovation. At present, it has adopted elements of kyara, anime, and manga, given that they are extremely popular in Japan; but in the future, it will assimilate anything else that becomes a significant part of popular culture. The next collaboration of the shrine is with the anime Sword Art Online and the reason behind it is the shrine's friendly relationship with the artist. $^{7}$

\section{Kyara in Ryōhōji}

The builder of the Shoeizan Ryōhōji 松栄山了法寺 was the Nichiren priest Keiun Nicchō 啓運日澄. He descended from Kyōto to Kansai region and constructed a study centre for the great scholars of Nichiren Buddhism in the Matsubagayatsu 松葉ヶ谷 area of Kamakura 鎌倉 in 1253. This is where he wrote many books on Nichiren Buddhism, such as the Hokke Keiun 法華啓運 (Lotus Sūtra of Keiun). Keiun was also a great scholar of the Nichiren School of Buddhism and, considering his knowledge and proficiency, he became the Head Priest of the Honkokuji 報国寺 in Kamakura. It was during that period that the idea of the construction of the Ryōhōji originated, primarily as a place for him to live a secluded life after his retirement.

During the Jōwa 貞和 period (1345-1350) the Honkokuji moved to Kyōto, with the Ryōhōji being moved from Kamakura and constructed in the Hachiōji area. Later, during the Momoyama 桃山 period (1568-1600), it was once again moved to the Entoku 延徳 area of Hachiōji, where it is currently located.

Along with the Ryōhōji Honzon 了法寺本尊 (the focus of devotion), also known as the Jikkai Dai Mandara じっかいだいまんだら, other objects of worship, often found in Nichiren Buddhism - specifically Benzaiten, Shichimen Daimyōjin 七面大 明神, and Kishimojin 鬼子母神—are hosted in the main hall of the temple. ${ }^{8}$

Ryōhōji's popularity greatly increased after it attained the nickname moedera 萌 え寺 (moe temple). But how did an old and perishing temple suddenly gain popularity and was labelled moedera? Since 2009, the Ryōhōji has collaborated with the production company Hachifuku はちふく to create a fusion of traditional Buddhist iconography and teachings and the popular cultural elements of kyara, anime, and manga. This

\footnotetext{
${ }^{7}$ Kishikawa Masanori's interviews and online communication through e-mails were translated from Japanese into English by the author.

${ }^{8}$ Information received from the pamphlet and the head priest of the temple Nakazato Nichikou.
} 
collaboration helped popularise the temple and presented a new, friendly, relatable, and reachable image of an otherwise traditional temple.

In May 2009, the entrance of the temple was embellished with a big illustrated sign of the moe-patterned versions of the deities enshrined in the temple. The main image is Benzaiten who was refashioned as a moe kyara wearing a mini-skirt and pink boots and renamed Torobenten とろ弁天 after its designer and cosplayer Toromi とろ 美. Her companions are the other deities enshrined in the temple, also refashioned as moe characters. The other deities in the sign include Kishimojin 鬼子母神, who was renamed mama, and Ugajin 宇賀神. The sign also features a QR code that is linked to a website when scanned by a mobile phone. The website, once opened, gives a brief introduction and explanation of each deity enshrined in the temple (Thomas 2015). During the interview with the head priest of the shrine Nakazato Nichikou on August 29,2017 , he said that initially he was a little wary about putting up the sign, but he tried omikuji (fortune telling paper strips) to see what the future beholds, and when dai-kichi 大吉 (great blessing) came out, he eventually made up his mind to install the sign.

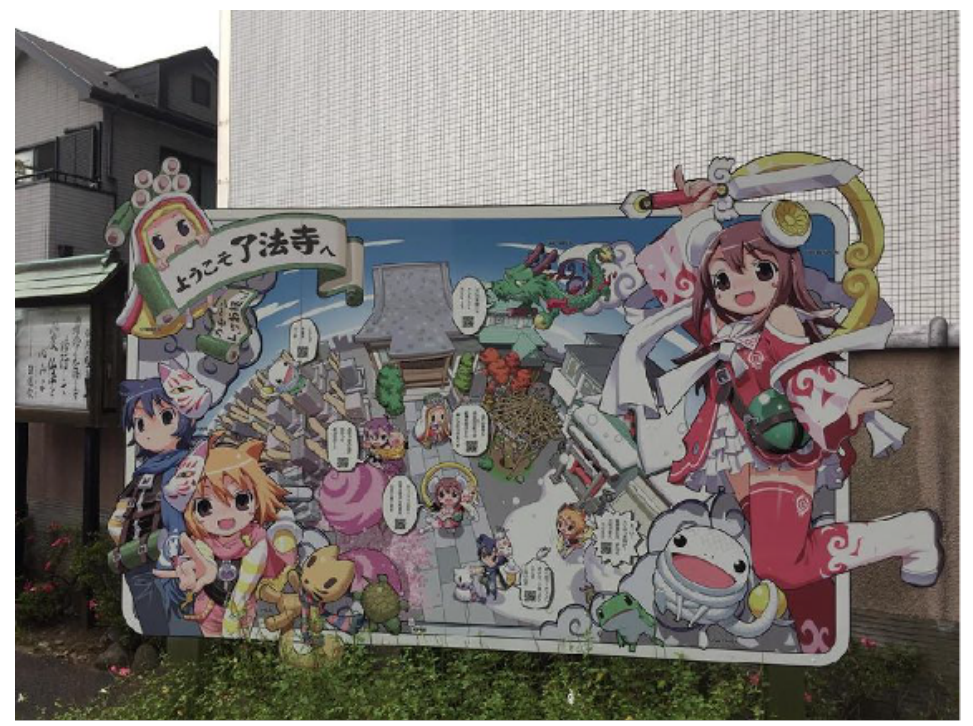

Figure 3: Sign of the moe-patterned versions of the deities in Ryōhōji, Hachiōji, Tōkyō. Photo taken by the author.

Toromi is the designer of the sign, who is a voice actor, character designer, illustrator singer, and composer. The installation of the sign attracted some popularity, which led to the foundation of a production company called Hachifuku. Soon after, 
the company started selling Ryōhōji-themed products, such as mugs, t-shirts, and folders, and went ahead to sponsor events, like the maid café event that was held on the temple grounds. It garnered mass attention from both the public and the media. NHK (Japan Broadcasting Corporation) also televised part of a programme exclusively on Ryōhōji with the caption “Colourful Temple Tour” (karafuru ji-in meguri カラフル寺 院巡り). During the maid café event, the visitors and temple parishioners were hosted by black and white maid costume wearing girls. The maids also played several games and sold numerous things - from food to trinkets - adorned with the moe-patterned image of Benzaiten and the other deities enshrined in the temple in the pop-up stalls inside the temple precincts (Porcu 2014; Thomas 2015).

In 2010, the renowned figurine maker Miyagawa Takeshi 宮川武 made a statue of Torobenten and donated it to the temple as a contemporary Buddhist statue. His work is highly appreciated and the statue rests inside the temple.

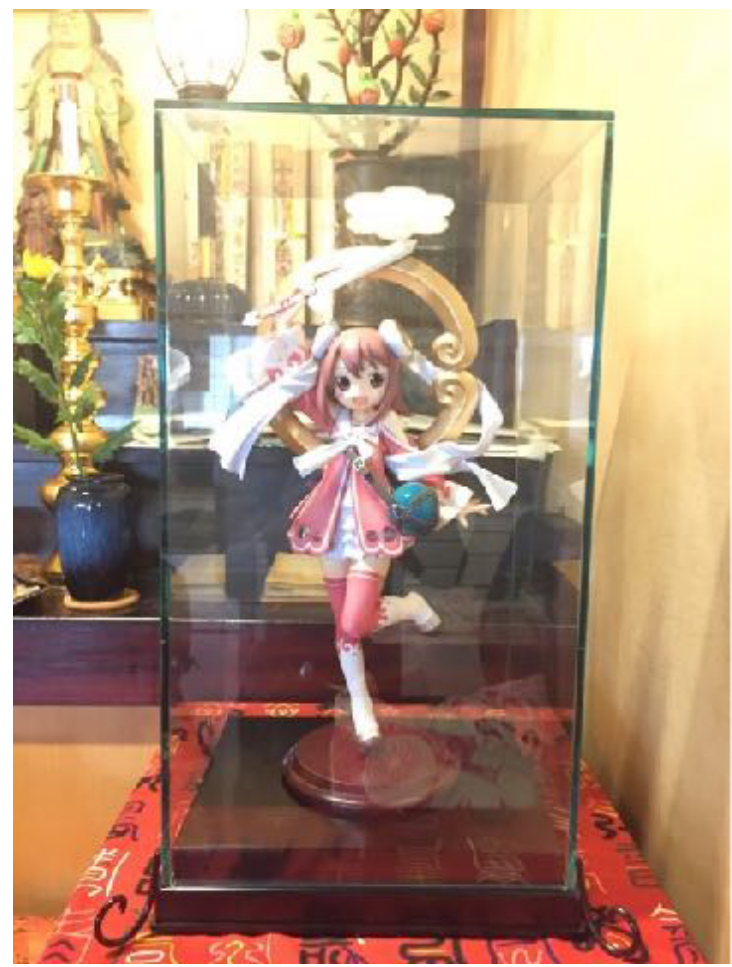

Figure 4: Moebutsuzo of Goddess Benzaiten (Torobenten) in Ryōhōji, Hachiōji, Tōkyō. Photo taken by the author.

In the same year, an original anime music video called Tera Zukkyun 寺ズッキュ $ン$ (Temple Thrill) was launched on YouTube and the temple homepage, with limited edition DVDs available for sale. The song featured Toromi who also wrote the lyrics 
and appeared in the video cosplaying as Torobenten. The music video is a medley of live action shots of Toromi and the animated versions of the temple grounds and the enshrined deities therein. The lyrics of the song contain some parts from the dharani section of the Lotus Sūtra. ${ }^{9}$ It also explains the importance of the practical benefits (genze riyaku 現世利益), especially focusing on its ability to facilitate romantic associations (en musubi). ${ }^{10}$ In the video, Torobenten is seen inviting her listeners and audiences to visit the temple and avail its benefits (Thomas 2015).

The successor of this song was another one called Namu XCyun なむ×きゅん (hail squeeze), starring an additional cosplayer called Kikoden Misa きこうでんみさ, who is a pornography actress and a minor celebrity or tarento タレント (talent). She cosplayed as the deity Kishi-Joten 吉祥天 turned into a moe kyara called Kikoden きこ でん. She differed from Torobenten as the latter was a cute rendition of the deity Benzaiten, while Kikoden was a sexualised rendition. The lyrics of the song were also quite eroticised (Thomas 2015).

This was followed by the release of a game for the Android operating system in 2012, which was then released on the iOS operating system in the next year. It is a card game where Torobenten helps ghosts and demons to abandon the path of evil and transform into magnificent deities. Another game called okyō no tatsujin お経の達人 (Sūtra Master) was also launched by Hachifuku earlier that year, in which the players with a background of the temple's theme song, strike a wooden fish, which is a traditional Buddhist practice. However, this game was withdrawn due to certain copyright infringement issues.

Other events also included introducing stickers on LINE—a free messaging and video calling app-with the catch phrase enmusubi 縁結び (karmic connections). Merchandise, manga, games, and DVDs were also sold in various manga conventions, like at the Comiket Convention in Tōkyō and itasha 痛車 (decorating one's car with their favourite manga and anime characters) conventions (Thomas 2015).

\footnotetext{
${ }^{9}$ Dharani is a spell or formula said to protect the one who recites it and benefits the person by its mystic power.

${ }^{10}$ Practical benefits or genze riyaku 現世利益, which are this-worldly benefits, constitute a central structure in Japanese religion sought through numerous ritual practices, symbolised by various ritual objects, such as talismans and amulets, and affirmed through textual traditions (Reader and Tanabe 1998).
} 


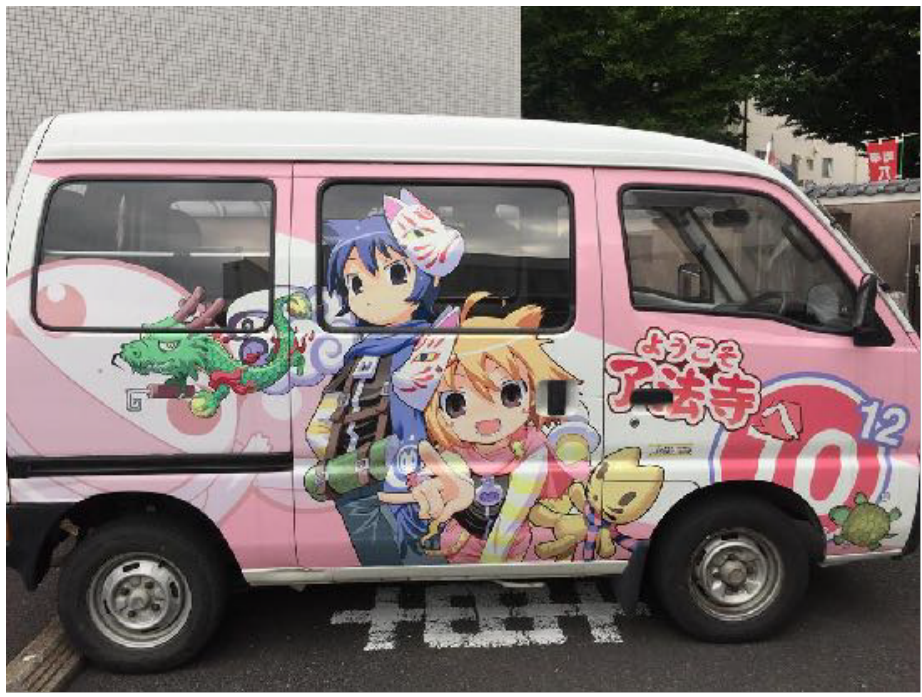

Figure 5: Itasha of moe-patterned images of the deities in Ryōhōji, Hachiōji, Tōkyō. Photo taken by the author.

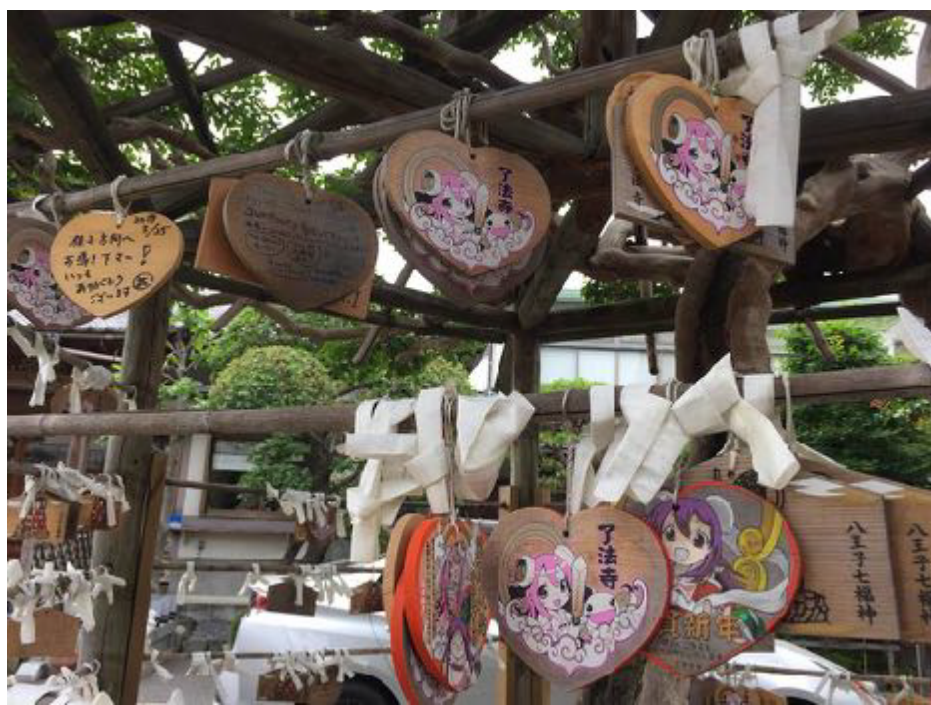

Figure 6: Ema with the image of Torobenten in Ryōhōji, Hachiōji, Tōkyō. Photo taken by the author. 


\section{Kyara in Ishiura Jinja}

Ishiura Jinja is the oldest shrine in Kanazawa, in Ishikawa Prefecture. The shrine is about 1,500 years old and is popular as the one that enables romantic relationships and marriages. The shrine is part of the Ōmiwa Jinja 大神神社, located in Sakurai 桜 井市, Nara prefecture 奈良県. The deity enshrined in the Ishiura Jinja is Ōkuninushi no Kami 大国主の神 (Shintō deity of love and marriage).

In 2008, the shrine started garnering a lot more popularity and visitors due to the introduction of a yuru kyara called Kima Chan, a half dog and half rabbit yuru kyara. Initially, the designer of this character, who is the wife of the high priest of the temple, designed it as a dog but eventually became more of a rabbit, given that a rabbit is also the messenger to the deity Ōkuninushi no Kami. ${ }^{11}$

Along with the omamori, ema, and goshuincho 御朱印帳 (shrine stamp book) with the image of Kima Chan, the shrine also sells several Kima Chan merchandise, such as memo pads, folders, notebooks, and even coffee.

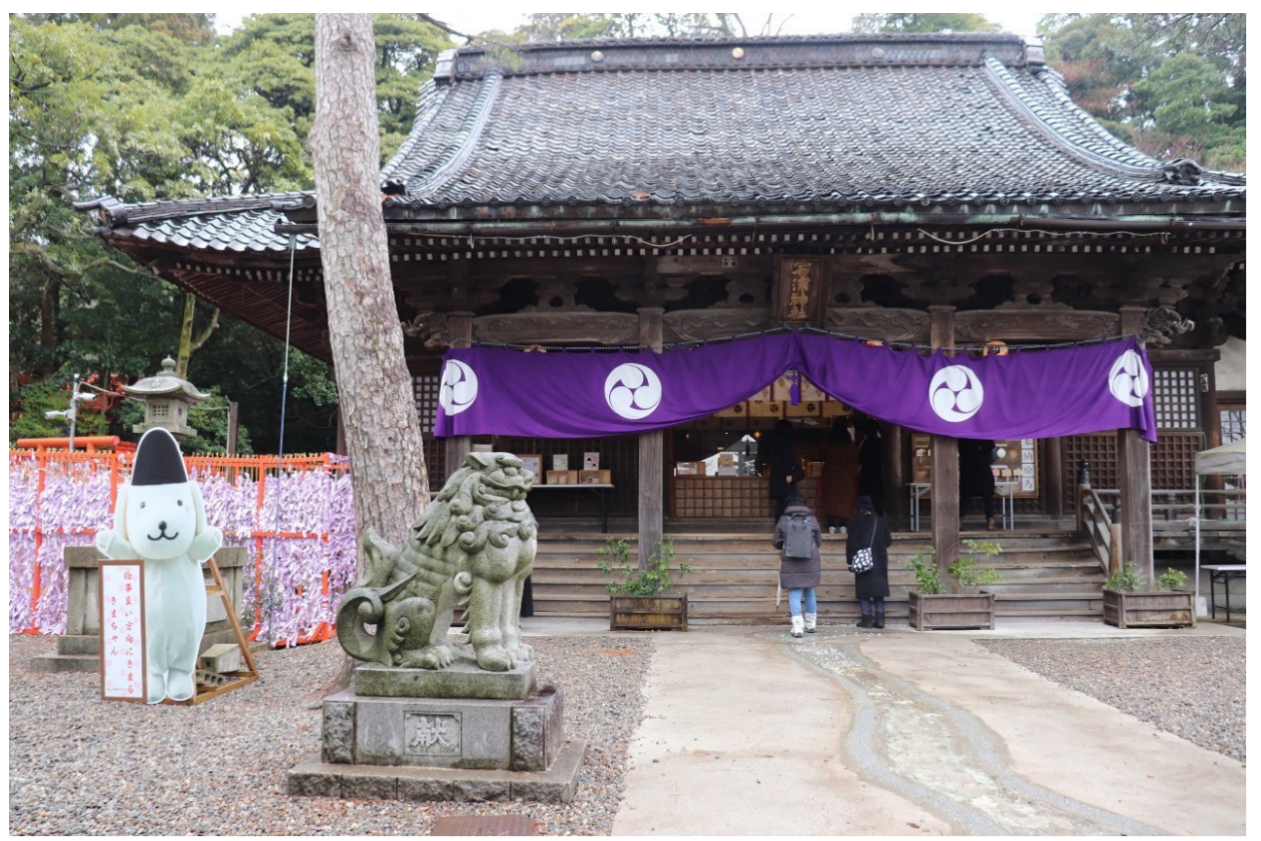

Figure 7: Ishiura Jinja with a cardboard cut-out of Kima Chan. Photo taken by the author.

\footnotetext{
${ }^{11}$ Information collected during the interview with the shrine maiden Ogawa Yoshinori 小川美範 on January 21, 2020.
} 


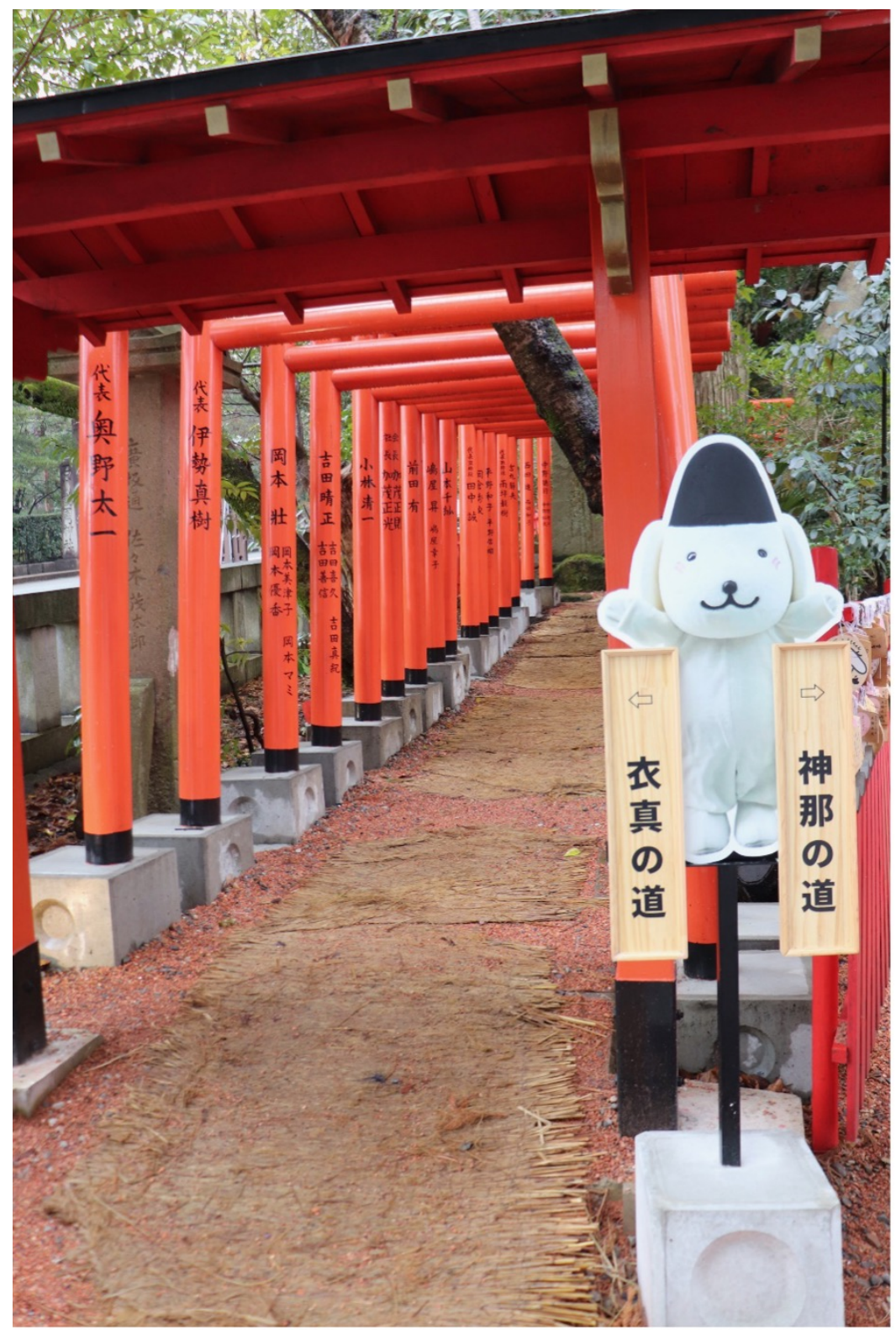

Figure 8: Cardboard cut-out of Kima Chan near the torii gates of Ishiura Jinja. Photo taken by the author. 


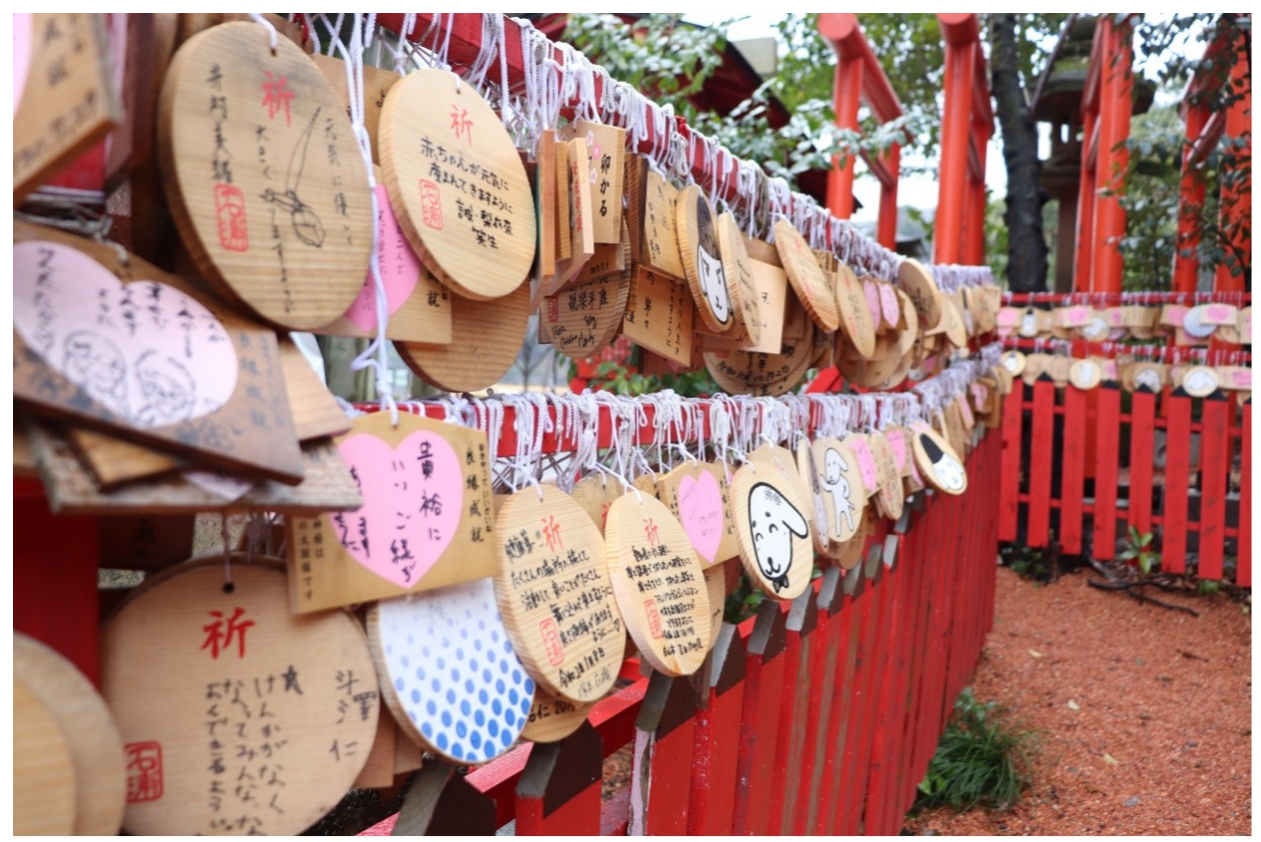

Figure 9: Ema with the image of Kima chan. Photo taken by the author.

\section{Reason behind the Infusion of Kyara in these Religious Spaces}

The introduction of a secular popular culture element like kyara into sacred religious spaces like the Kanda Myōjin, Ryōhōji, and Ishiura Jinja might initially seem odd and raise the question for such a practice. The reasons behind this could be manifold. It could be looked at from the angle of secularisation, consumerism, and globalisation. However, the aspects of play and entertainment within Japanese religion often overlooked.

In her study of the Ryōhōji, Elisabetta Porcu (2014) has pointed out that due to dwindling interest in religion in Japan, temples must find out new ways to reinvent themselves and increase visitors' interest and attraction, highlighting the secularisation theory. In her view, in the age of consumerism the rules are dictated by market logic, and religion must also keep up with these rules and use "branding" as a marketing strategy tool. Scholars like Mara Einstein (2008) talk about the urgent need of religious institutions to brand themselves and sell their products to find their place and meaning in this consumerist society. Einstein (ibid: 92) discusses "faith brands," that is, "spiritual products that have been given popular meaning and awareness through marketing" as well. Ryōhōji has done something similar by transforming the enshrined deity Benzaiten as a moe kyara, which resulted in being branded as a moedera (moe temple). Moreover, by being the only temple in Japan that houses a moebutsuzo 
萌え仏像 (moe statue of Benzaiten) whose nickname is Torobenten, the temple has created its unique brand object. In this way, both the temple and the company Hachifuku are benefitting. The temple is utilising the company's marketing strategy, whereas the company is profiting by the moedera brand of the Ryōhōji that they created. Similarly, it can be said that Kanda Myōjin has also branded itself as an anime shrine with the anime kyara Nozomi Tojo as its official idol.

The popular culture elements of kyara, manga, and anime are globally popular, which has encouraged the government to take a step forward and utilise them vastly in propagating the idea of "Cool Japan" as a major soft power tactic. These popular culture elements are therefore characterised as typical products and symbols of contemporary Japanese culture. An additional reason is that some religious spaces employ these popular culture elements in order to be part of this global contemporary image of Japan. Akihabara is the haven for manga, anime, and kyara fans. It enjoys immense popularity both in Japan and around the world. Being conveniently located in Akihabara, it can be said that Kanda Myōjin has also joined the bandwagon of the popular anime, manga, and kyara culture in order to be part of the global contemporary image of Japan.

Another reason discussed by Porcu (2014) and Adam Possamai (2005) for religious institutions to have meshed popular culture elements with that of religion is to proselytise and propagate religious teachings. However, the scope of the aforementioned reasons is limiting if the existing tradition of Japanese religion overlapping secular elements of play and entertainment with that of religion is overlooked.

\section{Market Spaces with Religious Connotation}

Although sacred spaces like Kanda Myōjin, Ryōhōji, and Ishiura Jinja doing secular commercial activities, like selling merchandise products and engaging in entertaining popular culture elements of kyara, might seem a little strange at first glance — or a desperate measure to deal with the constraints of a consumerist society - it is not a venture employed only in contemporary times. Historically, market spaces have always been a part of religious spaces. This can be explained by examining the religious connotation of market spaces in Hur's (2000) elaborate discussion of the commercial ventures in the Asakusa Sensōji 浅草浅草寺.

Asakusa Sensōji, the abode of the powerful Asakusa Kannon 浅草観音, became a hub of trade, commerce, and entertainment during the Tokugawa period. The temple complex, consisting of the Main Hall of the Asakusa Kannon and other important religious structures, is called the inner precincts (keidai 境内) of the temple, and it is supposed to be a sacred space with a divine ambience separated from that of the secular world. However, even the inner precincts of the temple were filled with commercial complexes. Among an array of commercial activities, some of them were food stalls, toothpick stalls, teahouses, and storytelling halls about the Buddha. 
However, these secular commercial activities also had a religious connotation. The ancient deities were believed to be involved in markets, and traders would at first ritually offer their commodities to the deity before engaging in trade. Markets in the ancient times were perceived as sacred spaces separated by sakaki 棉 trees $^{12}$ or rocks and they served as grounds for prayers, rituals, and singing and dancing parties (utagaki 歌垣). Several shops in Asakusa sold omamori, and the purchasing of amulets and talismans fell under the parasol of prayer which is a religious activity. Certain shops sold Asakusa staple products like rice cake, liquor, etc., which were supposed to possess divine powers that could expedite the salvific powers of the Asakusa Kannon (Hur 2000).

This shows how, historically, market spaces had religious undertones and were intrinsically connected. Therefore, it can be argued that having commercial activity in religious spaces has religious roots and it is not just a contemporary need of a consumerist society. Although Kanda Myōjin cannot completely be detached from the market dynamics of a consumerist society having a Love Live merchandise shop within the shrine complex, the market dynamics cannot fully explain its presence either. In a way, it can be argued that commercial activities and religious sites always went hand in hand. With changing times and interests, the commercial stalls and shops have changed from teahouses, toothpick stalls, and food stalls to ones selling anime/manga- and kyara-related products in certain religious spaces.

\section{Religion, Play, and Entertainment}

Historically, Japanese religious spaces and religious traditions have always experienced the conflation of play and religion. In the Kojiki and Nihon shoki 日本書紀 there are various accounts that talk about kami and vindictive spirits being allayed by different types of entertainment, such as dancing, singing, and other musical forms. These activities are ascribed to the term kami asobi 神遊び (divine plays). For instance, when the sun goddess Amaterasu hid herself in a cave depriving the universe from light because of her brother Susanoo's raucous behaviour, it was the goddess Ame no Uzume 天宇受賣命 who performed a spectacular dance to lure Amaterasu

\footnotetext{
${ }^{12}$ Sakaki tree or cleyera japonica is an evergreen tree which is considered to be sacred in Shintō. In Shintō rituals, the branches of this tree are used as offering wands (tamagushi 玉夰) presented before the kami. Branches of sakaki tree are often used as decorations, purification implants, and handheld props (torimono 採物) in ritual dance. It is generally used in Shintō rituals to demarcate a space as sacred. Being evergreen, it serves as a symbol of nature's continuity. In the myth of sun goddess Amaterasu 天照 written in the Kojiki 古事記, when the goddess hid in a cave angered by the rebellious behavior of her brother Susanoo スサノオ, the universe was covered with darkness. At that time, the sakaki tree was decorated with mirror, jewels, and a sword as part of a grand festival to lure Amaterasu out of the cave and bring back light into the universe. The attempt was successful and the sakaki tree is believed to be sacred ever since (Rusu 2012).
} 
out of her cave and bring back light into the universe. The various forms of entertainment, like dengaku 田楽 (field music) and sarugaku 猿楽 (monkey music), that were performed in Buddhist temples and Shintō shrines for fund-raising (kanjin 勧進) also have their origin in kami asobi. Parts of Orikuchi Shinobu Zenshu 折口信夫全集 (Complete Works of Orikuchi Shinobu) illustrate that the Japanese people believed that they could communicate with, appease, and acquaint the deities, and even associate themselves with them if they were able to "play with" or entertain them. Hence the religious professionals in the Yamato imperial court, who were believed to be able to communicate and deal with the supernatural spirits were called asobi-be 遊び部 (play functionaries) (Hur 2000).

The temple Asakusa Sensōji also served as a venue for commercial ventures, such as several misemono 見世物 (display of things) - like exhibits of exotic birds and animals, people with deformities, puppets, life like dolls, etc. But these misemono exhibits also had religious undertones. These items have their origins in the saiku 細 工 (delicate handicrafts), which were used as offerings in traditional Shintō matsuri. With time, the matsuri became more of a spectacle with pompous and ornate processions, and the saiku offerings changed into mere ornaments of the portable shrines. Soon they became side exhibits to attract spectators, and the misemono exhibits in the Sensōji during the late Tokugawa period, although far removed from its original religious connotation, remained a part of the traditional religious structure since they were exhibited on a religious site (Asakura 1977).

Although the term misemono was coined in the Tokugawa period, several activities, like the misemono street performances, took place in front of Buddhist temples and Shintō shrines as part of fundraising shows. Misemono of deformed people were used to preach the Buddhists teachings of karma and reincarnation, according to which one's wrong doings in this life could lead to deformities in the next (Hur 2000).

The "common religion"13 of Japan is an amalgamation of ideas, beliefs, and an approach towards life according to which the notion of entertainment and play is central. It is not comprised of a strict doctrinal system with sharp distinctions between the sacred and play, but rather envelopes both in its expression.

Many scholars, like Elisabetta Porcu (2014) and John Nelson (2012), find the idea of Japanese religious spaces incorporating popular culture elements to be an uncanny and frantic need to keep religiosity and religious spaces relevant given the constraints of consumerism and secularisation of the contemporary Japanese society. However, the incorporation of popular cultural elements like kyara is far from unusual, given that entertainment, play, and religion have always been interrelating concepts in Japanese religion.

\footnotetext{
13 "Common Religion" of Japan refers to "a set of sentiments, behavior, practice, beliefs, customs, and the like that is shared by the vast number of people and is common to all classes and groups in society" (Reader and Tanabe 1998: 29).
} 
Hence, the interrelationship between play, entertainment, and religion in Japanese religion indicates that the introduction of kyara in certain religious spaces in Japan seem more like an organic process of change and evolution from more traditional forms of entertainment (like dengaku, sarugaku, and misemono) to immensely popular pop culture elements like kyara, anime, and manga.

\section{Entertainment and Shintō Matsuri}

A Shintō matsuri is both a religious and cultural phenomenon that enables a renewal of life energy for both the kami and the people who participate. It consists of two elements: a sincere ritual that is performed within the boundaries of tranquillity and order; and entertainment and festivity that display collective exhilaration, spontaneity, and disorder (Moriarty 1972).

In his detailed accounts of the Shintō matsuri, Herbert Plutschow (2013) describes that play and entertainment aspect. The matsuri follows three major sequences, namely kami oroshi 神風, kami asobi 神遊び, and kami okuri 神送り. These determine the annulment, recovery, and renewal of time and order. This ritual reestablishment of order accomplished through singing and dancing during the matsuri is called kami asobi. This playfulness of Shintō festivals shows how play and religion are closely related.

Kanda Matsuri, which is an important festival of Kanda Myōjin, also displays both the elements of religion and ritual and that of entertainment and festivity. But the latter is changing with time. In his interview, Kishikawa Masanori (junior priest of Kanda Myōjin) mentions that the entertainment aspect of Kanda Matsuri has been an everevolving process. From collaborating with different anime for the poster of the Kanda Matsuri, making anime/manga-themed floats, holding yukata 浴衣 (a casual kimono 和服) contests, manga exhibitions, and pro-wrestling championship for women to calling baseball players from the popular baseball team Yomiuri Kyojingun 読売巨 人軍, there has been a significant diversification of the entertainment aspect of the Kanda Matsuri keeping in terms with the changing times and needs. ${ }^{14}$

Hence, secular commercial activities, entertainment, and religion have been overlapping with existing traditions, although their forms are different and have evolved in time. Like Japanese religious spaces, commercial ventures like markets also had religious connotation. Rituals and practices in textual traditions, as well as play, entertainment, and religion in religious festivals have always been intertwined concepts.

\footnotetext{
${ }^{14}$ Interview of Kishikawa Masanori conducted on September 13, 2017.
} 


\section{Kyara in Japanese Religious Landscape: The Impact}

This section is an attempt to understand what kind of impact is made on the practice of religion by the incorporation of kyara in certain religious spaces in Japan. The various elements of shūkyo asobi 宗教遊び are being utilised in the context of Kanda Myōjin, Ryōhōji, and Ishiura Jinja to analyse the effect it has on the practice of religion in these spaces. ${ }^{15}$

Although scholars like Porcu (2014) highlight a secularisation process by talking about the decreasing interest of religion in Japan leading temples and shrines to reinvent themselves by utilising popular culture elements like kyara, this might not be completely accurate. In the 1970s, when the secularisation theory was at its pinnacle, several Japanese sociologists questioned its successful application in Japanese society and provided certain counterarguments. One was a rise in "spirituality," maintaining that religion has only been transformed from traditional institutions to newer forms and has not actually been diminishing as claimed by secularisation theorists. Scholars like Shimazono Susumu 島薗進 (2004) and Kashio Naoki 樫尾直樹 (2010) talk about such significant rise in the idea of spirituality in Japan. They argue that whereas the role of traditional religious institutions might be declining, religion has found its voice through "new spirituality." ${ }^{16}$ Shimazono (2012) suggests that contemporary Japanese religiosity is transforming and being deployed into other areas. Another argument is that of the "pilgrimage boom" (junrei bumu 巡礼ブーム), citing the case of the Shikoku pilgrimage. Masato Mori 森正人 (2005) and Ian Reader (2007) have talked about the rising number of pilgrims in the Shikoku pilgrimage (Shikoku henro 四国遍路) that has even surpassed the widely popular Saigoku pilgrimage (Saigoku sanjüsansho 西国三十三所) because of its extensive use of mass media, like television broadcasting, photo-essays and photo-magazines, cultural travelogues, documentaries, and so on. Hence, these scholars maintain that religious practices are still a significant part of modern Japan given the rise in pilgrimage.

Considering further the argument of religiosity in Japan as being transformed, renovated, and arrayed in different places, this section will show how in the case studies of Kanda Myōjin, Ryōhōji, and Ishiura Jinja, the fusion of popular culture elements

\footnotetext{
15 "Shūkyō Asobi refers to religious entertainment and playful religion, pointing to instances where modification of religious behavior and outlook occur within spaces equally devoted to entertainment or, alternatively, where religious practice and pedagogy simultaneously behave as entertainment experiences" (Thomas 2012: 17).

${ }^{16}$ In the 1970s and 1980s, "new spirituality" gained momentum and eventually achieved great success in Japan with its assimilation in popular culture. "New Spirituality" is referred to as something that has an essence of religiousness in the broad sense of the term but is not part of an organised religion or doctrine. The other implication of the term is the renewal of a kind of religiosity within an individual which would permit the individual to be religious and non-religious concurrently (Shimazono 2012).
} 
like kyara in religious spaces has led to a certain kind of recreation/reinvention of religion in those spaces. This process will be explained by examining the different elements of shūkyō asobi in the context of Kanda Myōjin, Ryōhōji, and Ishiura Jinja. The elements of shiukyo asobi could turn seemingly secular spaces and events into ones with religious undertones and vice versa, enmeshing religion and entertainment into one absolute whole.

The various elements of shūkyō asobi are as follows : "(1) can be viewed as religious in its production or consumption, (2) can also be said to be one of the many alternative strategies for negotiating spiritual needs in post-war and postmodern social circumstances, (3) draws upon but also modifies, existing religious themes, (4) can have a moral or spiritual effect on the audience, including an effect on how people view or practice religion, not necessarily limited to a sect or specific doctrine, (5) allows for oscillations between religion and entertainment while nevertheless referring to the space where the two overlaps; and (6) therefore isolates those moments where entertainment experiences provide the impetus or environment for religious learning or behavior, or where religious doctrine, ritual and pedagogy acts as modes of entertainment" (Thomas 2008: 78).

\section{Shūkyō Asobi at Kanda Myōjin}

During several visits to the shrine, interviews with different people visiting the shrine were conducted. A Japanese couple in their mid-thirties was visiting the shrine all the way from Hokkaidō 北海道. The man worked in a company and his wife was a homemaker. They visited the shrine because they were both avid Love Live fans and wanted to visit the place where their favourite character from the series, Nozomi Tojo, is the official idol. They bought an ema and several omamori both with the picture of Nozomi Tojo. When asked if they bought these only because Nozomi Tojo is their favourite character and both these tablet and amulet have pictures of the character drawn on it, the woman replied: "I did not buy the ema and omamori because it has pictures of Nozomi Tojo but because I generally write my wishes on an ema and buy omamori for me and my friends whenever I visit a shrine and since this shrine is famous for its collaboration with Love Live, I bought these special ema and omamori." When asked if she finds any difference between the traditional ema and omamori, she replied: "I don't find much difference between the two since both are purchased for good luck and to make a wish. But these ones that I bought in Kanda Myōjin are more special to me since they have my favourite character in them. I think Nozomi Tojo will help me in granting my wishes even more." Here, the religious significance and the veneration of these products does not seem to be missing. They are not just consumed as popular culture merchandise products but also as religious ones.

This point encapsulates the idea of modifying existing religious themes. Purchasing ema and omamori is part of an existing Japanese religious tradition. However, placing kyara images on them is part of modifying this tradition, wherein the other- 
wise religious products like ema and omamori start appearing as secular popular culture products. But when examined closely, they overlap between a secular and religious product, and often do not lose their religious significance.

Kanda Myōjin's collaboration with the anime Love Live and its adaptation of Nozomi Tojo as the official idol makes Kanda Myōjin a religious site that oscillates between the sacral and entertainment aspects - or merges the two. While visiting the shrine and interviewing several people, it was observed that many shrine visitors who are ardent fans of the Love Live anime visit the shrine because of its collaboration with the anime but nevertheless also treat the space as religious grounds and perform the necessary rituals. A couple I interviewed was from Tōkyō, both in their late twenties and both worked at a company. They identified themselves as lovelivers. They looked like typical anime fans, whose clothes and make-up were also inspired by anime-style. They gave me a lot of information about the shrine and its collaboration with Love Live and mentioned that they were frequent visitors to the shrine, since their idol Nozomi Tojo was also adopted as the official shrine idol. When asked if they perform omairi お参り while they visit the shrine, they replied: "Of course we do, every time we visit." However, they mentioned that it is only Kanda Myōjin they visit and no other shrines. Here it can be seen that, even for lovelivers, Kanda Myōjin is not just an entertainment space due to its association with their favourite anime or the character, but also a religious space that requires adequate reverence, making the shrine a space where religion and entertainment are merged.

Another interviewee, a middle-aged man working at a company in Tōkyō, said: "I like visiting shrines and praying; however, I particularly like coming to Kanda Myōjin since it is also the site of my favourite anime and I can buy various Love Live related merchandise products from the shop here." For this man, Kanda Myōjin is not only a place for prayer - that is, a religious activity — but also one of entertainment.

However, the same cannot be said for all visitors, especially the anime fans. For some, the shrine might only be a space for entertainment since it possesses a Love Live merchandise shop in its precincts. An interview with a middle-aged man who did not want to disclose any kind of personal information revealed the following: "I come to the shrine only to visit the Love Live merchandise shop and buy any new and interesting merchandise products that have arrived at the shop." After saying that, he left in a hurry towards the merchandise shop and purchased some Love Live merchandise products. In this case, the shrine (or the shrine grounds) only becomes a space for entertainment and a commercial venture. Another feature that Kanda Myōjin highlights is that sometimes it also affects the perception of how people who visit this space view or practice religion.

In an interview with a university student from Mie prefecture 三重県, it was stated that his repeated visits to Kanda Myōjin have stirred an interest in him to visit other shrines around Japan as well: "I came to Kanda Myōjin since I am a Love Live fan but my frequent visits to Kanda Myōjin have aroused an interest in me to visit other 
shrines around Japan. This interest aroused especially after I purchased the special Love Live edition of Goshuin-cho from the shrine and the priest did the beautiful calligraphy on it." Although just an anime fan, the interviewer began visiting shrines, performing omairi, and enjoying such shrine visits, thus having an impact on his practice of religion.

Another interesting observation emerged during an interview with a family visiting from Saitama prefecture. The family included a couple, their middle school daughter, and her paternal grandmother. The mother happens to be a University of Tsukuba 筑 波大学 graduate. She is now a homemaker, and the father works at a company. Both the father and the daughter are big Love Live fans and therefore decided to visit Kanda Myōjin. When asked if they knew about Kanda Myōjin before watching the anime, the father replied: "I heard the name of the shrine but did not know much about it. It was only after watching Love Live that we wanted to visit it." The mother added: "We visit our nearby shrine only during hatsumode 初詣 [the first Shintō shrine visit of the Japanese New Year] but having my husband and daughter interested in visiting this shrine, it was a good opportunity as a family to come for a shrine visit." I then asked the grandmother if she knew about Kanda Myōjin, to which she replied that she knew fairly well about the shrine and that some of the deities from the Shichifukujin were enshrined here. She expressed her happiness and gratitude to be able to come and pray here. Within the same family, the shrine becomes a space for entertainment for the father and the daughter, and a space for prayer for the mother and the grandmother. The purpose of visiting is simultaneously religious and for entertainment.

Another point that this interview propounds is the idea of subjective myth. For the father and the daughter, the shrine becomes relevant only because they have watched it in their favourite anime and because the daughter's beloved character Nozomi Tojo happens to be the shrine's official idol and the shrine maiden. For her, and even her father, the shrine is significant because of this reason alone. They are not really concerned about the deities that are enshrined here. It is more important for the daughter to write a wish in an ema with a Nozomi Tojo picture because, like the couple from Hokkaidō, this young girl also believes that it is Nozomi Tojo that will help her fulfil her wishes. The enshrined deities and their stories do not hold much significance neither for this girl nor for her father.

Two more interviews conducted with a university student and a middle school student also iterate this point. Neither of the two knew about Kanda Myōjin or the enshrined deities before watching the anime Love Live and, for both interviewees, Nozomi Tojo conveys a very significant image of awe and admiration. Here the idea of the creation of a "subjective myth" is being formed. "Subjective myth" is a set of images and ideas known primarily to the individual self. The consumers of popular culture choose and interpret freely certain parts of this set and then create their subjective myth that has an explanatory power only with regard to the individual self (Possamai 2005). In these cases, it can be observed that it is the official idol of the 
shrine, Nozomi Tojo, who is being admired and even reverenced. These shrinegoers believe that it is her presence in the shrine precincts as an official idol or her image on the ema and omamori that will help in bringing them luck or fulfiling their wishes. Although the shrine does not place the kyara in any position of veneration, it is the fans who visit the shrine that have placed her in such a position, therefore creating a subjective myth. Thus, Kanda Myōjin displays several elements of shūkyō asobi.

\section{Shūkyō Asobi at Ryōhōji}

In the case of Ryōhōji, it can be observed that the popular culture element has modified existing religious themes. This can be substantiated by the example of the Torobenten hōnōsai 奉納祭, or the ceremonial unveiling of the moe statue of Torobenten, which took place in the main hall of the temple in November 2010. Here the amalgamation of the religious and the entertaining attributes can be observed. The ceremony was performed by the head priest who wore the traditional Buddhist attire worn during the most illustrious religious ceremonies, whereas Toromi, the designer of Torobenten, was dressed as Torobenten and performed the unveiling of the statue in the style of pop culture. In addition, there were several chairs in the front row that seated life-sized, school-uniform-wearing moe dolls together with danka 檀家—a continuing affiliation between Buddhist temples and households in Japan practiced since the Heian period (794-1185) - members and fans. Toromi then performed a type of ritual blessing in front of the main hall. She used a big pink hammer made of plastic to hit the head of her fans who were kneeling at the temple stairs. She also performed a small concert and sang her song Tera zukkyun! Ai no Ryōhōji 寺ズッキュン! 愛の了 法寺 (Porcu 2014).

Another example is that of the creation of the moebutsuzo (moe statue of Benzaiten). The transformation of the traditional image of Benzaiten into that of a moepatterned image is the modification of a traditional image of a deity into that of a popular culture one that is placed inside the temple along with the other enshrined deities. During the interview with the head priest of the temple, Nakazato Nichikou, he was asked if the moe butsuzou can be considered a sacred entity at par with the other enshrined deities, to which he replied: "The image of Buddha and kami sama has changed over the years and the perception of this image is different from person to person, so the moebutsuzo is sacred for the people who believe it to be so and it can be said to be an image of kami sama." In this case, the existing traditional image of Benzaiten is modified into a new popular culture version that is not done only for entertainment purposes; it is also elevated to a position of reverence and veneration.

Ryōhōji is also a religious site that oscillates between the sacral and the entertainment aspect - or merges the two. For example, there was a maid café event within the temple precincts in November 2009. During the event, the visitors and temple parishioners could enjoy being attended by maids dressed in black and white maid costumes. 
In the pop-up stalls installed within the temple precincts, the maids played games and sold numerous things, from food to trinkets, adorned with the moe-patterned image of Benzaiten and the other deities enshrined in the temple (Porcu 2014). During this time, the temple grounds turned into an entertainment site of a secular commercial activity.

In 2010, the day of Hana Matsuri (April 8) that is traditionally celebrated as Buddha's Birthday was transformed into a popular culture event within the temple. The head priest performed the traditional religious ritual of hearing a sermon (howa 法話) while Toromi cosplayed as Torobenten (Goddess Benzaiten who has been refashioned as a moe kyara) sang the "Happy Birthday" song to Buddha in English. Subsequently, a cake cutting ceremony for Buddha's birthday took place (Porcu 2014). In this instance, the temple becomes a hybrid site of entertainment and religious activity. The presence of Toromi dressed as Torobenten, performing the "Happy Birthday," and cutting the cake constitutes the entertaining aspect, with the ritual of howa and the celebration of Hana Matsuri being religious significance, transforming the temple grounds into a site that merges the two.

During hatsumode (first shrine visit) event on January 3, 2020, I conducted several interviews. Two middle-aged men came to the shrine from Tsukuba つくば市, Ibaraki prefecture 茨城県. They found out about the shrine on the internet in 2009 and have been visiting every year ever since. One of them said that he had an interest in mythology and read several books on the topic. He said: "Ryōhōji is special to me because it has Torobenten. I think she is the new image of Benzaiten since the idea of god changes according to how people believe and perceive it. A few years back they use to give small figurines of Torobenten but they do not do that anymore. I wish I had one so I could keep it in my kamidana [神棚] at home.” Another interviewee, who also had a keen interest in religions and read books written by Yanagita Kunio 柳田國男 (1875-1962), had the same view: “Japanese Gods have no form and hence any figure can become god if the spirit of Buddha is put into the sculpture or picture of the butsuzo (仏像; statue of Buddha).”

In these interviews, the moebutsuzo of Torobenten is perceived by many people as the new image of Benzaiten and is held in the same esteem as that of a traditional image of Benzaiten. The moebutuzo of Torobenten is not simply regarded to be a secular popular culture product. This is an example of how an existing religious theme of a long-established image of Benzaiten is modified and the impact it has on people in their practice of religion.

\section{Kyara: Messenger to Kami}

An interview with the shrine maiden Ogawa Yoshinori of Ishiura Jinja, who also wore the Kima Chan costume and was in the Kima Chan kigurumi (costumed character) form, was conducted on January 21, 2020. This interview gave an insight into how the introduction of a Japanese popular culture product like yuru kyara was perceived 
by the people, and what meanings were attached to this yuru kyara, namely Kima Chan.

When asked how is Kima Chan perceived by the people, Ogawa responded: "Kima Chan can be termed as an in-betweener kyara, a bridge between kami and people since people perceive it as a messenger of kami and ask Kima Chan for their wishes." When asked how did she personally perceive Kima Chan, she replied: "I do feel that Kima Chan is the messenger of kami sama especially when I meet people who say that their wish got fulfilled after they met Kima Chan." She also described that she initially felt uneasy to wear the Kima Chan costume, but later realised how powerful and influential it was and she herself became a fan of Kima Chan: "I understood the power and charm of Kima Chan." She also added that she felt that the message of the shrine being an important and sacred place got revitalised and renewed through Kima Chan.

The status of a mascot character being exalted to that of a messenger of a deity by the people who believe in its power to grant wishes yet again shows how the kyara stand in the threshold of being concurrently sacred and secular. The presence of kyara in religious spaces is viewed as natural and organic by the Japanese people since it has its roots in traditional elements of Japanese religiosity; hence, they are accepted and embraced by the people without a hint of hesitancy. An earlier case study of the Yuru Kyara Grand Prix ゆるキャラグランプリ in Matsuyama 松山市, Ehime prefecture 愛媛県, solidified this position.

\section{Yuru Kyara Grand Prix 2016 in Matsuyama}

In 2010, the Yuru Kyara Grand Prix was created. It is a contest to judge the best yuru kyara among the thousands that take part in the contest. It takes place in different parts of Japan and is attended by millions of people. One of the most popular yuru kyara is that of the Kumamoto prefecture called Kumamon. The fuzzy black bear with red rosy cheeks is immensely popular in Japan with a massive fan following. In 2014, the Bank of Japan announced that the sales of Kumamon merchandise was over two billion dollars, with an economic impact surpassing millions of dollars more in the Kumamoto tourism and industry (Sutera 2016).

The 2016 Yuru Kyara Grand Prix was held on November 5 and 6 at Shiroyama Park 城山公, 園 in the Horinouchi 堀之内 area of Matsuyama, Ehime. A total of 1,421 yuru kyara participated in the event and was visited by over 80,000 people from all over Japan. The winner of the contest was Shinjou-kun しんじょう君, which is the mascot of Susaki city 須崎市, in Kōchi Prefecture 高知県, and is based on the NihonKawauso 日本獺, that is, a Japanese river otter that was last seen in the city's Shinjou River しんじょう川. His hat is made of the city’s signature dish nabeyaki ramen 鍋焼 きラーメン and it is believed that anyone who touches his belly button will be a bearer of good luck. This quality immediately makes it somewhat of an engimono. Several yuru kyara in the event were designed based on yōkai or engimono. Two of them will 
be discussed here: Oidashi Neko 追い出し猫 from Miyawaka city 宮若市 in Fukuoka prefecture 福岡県, and Naruma なるま from Kochi city 高知市 in Kochi prefecture.

Oidashi Neko has its own origins story. About four hundred years ago, during the Edo period, a priest very fond of cats lived in a temple called Saifukuji 西福寺 in the Nekozuka 猫塚 area of Miyawaka. The temple was once attacked by a big rat that created mayhem in the temple and brought about many problems to the priest. The cat was not able to resolve the issue and, therefore, the priest summoned hundreds of his friends who had a big battle with the rat until it was defeated. The battle, however, resulted in the deaths of many cats. The priest was very touched by the sacrifice of the cats and built a burial mound for them and held Buddhist funeral services. The district from then on started to be called Nekozuka and the Oidashi Neko was created as a lucky charm to drive out evil and invite goodness. It has faces on both sides, one that brings luck and prosperity and another that drives away bad fortune and ill omen. ${ }^{17}$

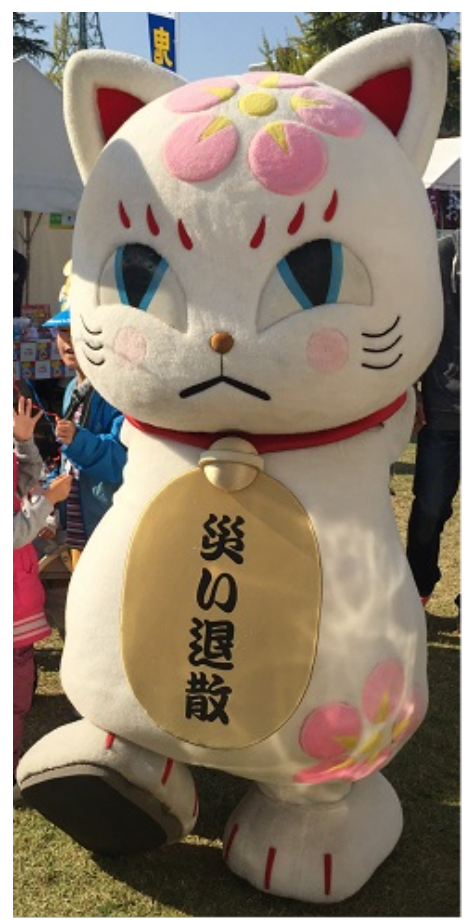

Figure 10: Oidashi Neko: yuru kyara for Miyawaka city, Fukuoka prefecture. Photo taken by the author.

\footnotetext{
${ }^{17}$ Information from the pamphlet of the Miyawaka Oidashi Cat Promotion Association.
} 
Naruma from Kochi city is designed based on the engimono daruma 達磨 doll and it holds an actual daruma doll in one hand and a naruko 鳴子 (clapping toy used during the yosakoi よさこい dance of a Japanese festival) in the other. ${ }^{18}$ Therefore, its name a combination of the word na な from naruko and ruma るま from daruma. The former signifies the famous yosakoi (traditional form of dance) festival of Kochi city, and the latter symbolises the famous dharma sunset in the Sukumo Bay 宿毛湾 (Kochi), given that the dharma sunset seems like a daruma doll. ${ }^{19}$ Naruma itself then becomes a good luck character that brings good fortune to whoever possess it.

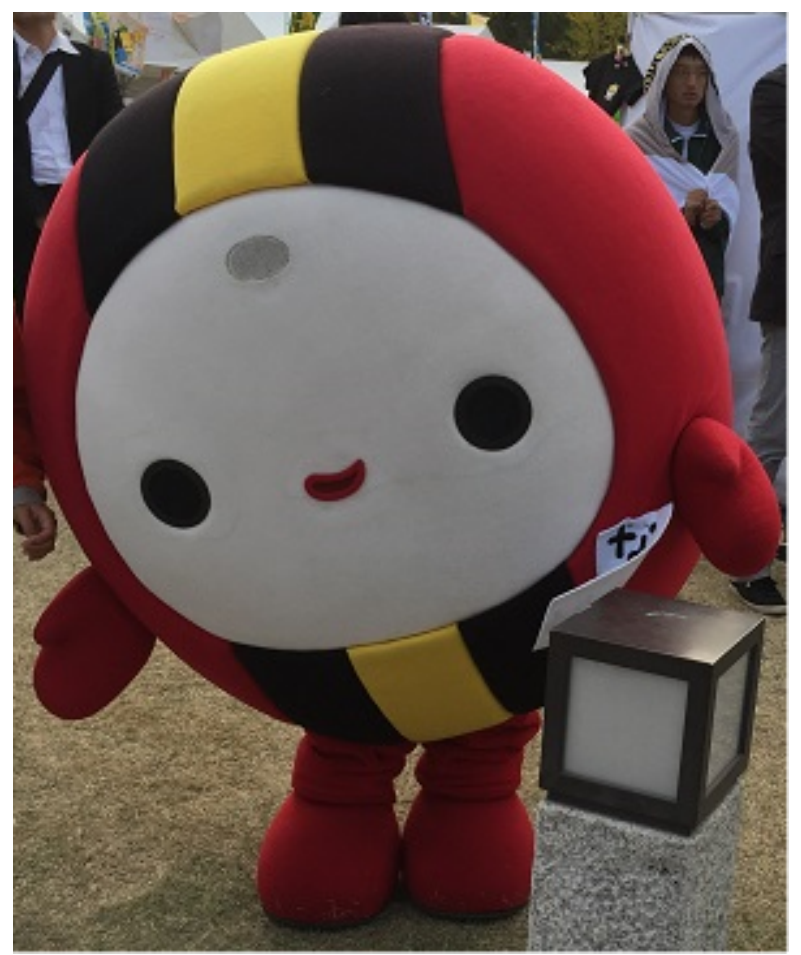

Figure 11: Naruma: yuru kyara for Kochi city, Kochi prefecture. Photo taken by the author.

\footnotetext{
${ }^{18}$ The Indian monk Bodhidharma, known in Japanese as Daruma, is believed to be the person who brought Zen Buddhism to Japan from China in the sixth century CE. A popular image of Daruma in Japan is of a tumbling doll. Initially, the Daruma dolls were utilised as talismans to protect children against smallpox, leading to their popularity as a guardian for children and the ones who bring good luck. The Daruma dolls come with no eyes and the common belief is to draw one eye, make a wish, and then draw the other eye when the wish is fulfilled (Faure 2011).

${ }^{19}$ Dharma sunset is named after the monk Bodhidharma, who is the image for the daruma doll in Japan.
} 
Engimono are portable objects in which the power of the deity or a sacred locality is being encapsulated. An engimono effectively emits the power of the sacred locality or deity at a distance from the sacred sites and brings about luck and well-being to the people who possess it (Daniels 2003). Given that the engimono are religious objects, the yuru kyara that are designed based on them illustrate how yuru kyara also have a certain religious connotation.

The yuru kyara based on yōkai are Kuruppa くるつぱ from Kurume city 久留米市 of Fukuoka prefecture based on a kappa 河童, ${ }^{20}$ and Konyudoukun こにゅうどうくん from Yokkaichi town of Mie prefecture based on a yokai termed as Akaname 垢嘗. ${ }^{21}$

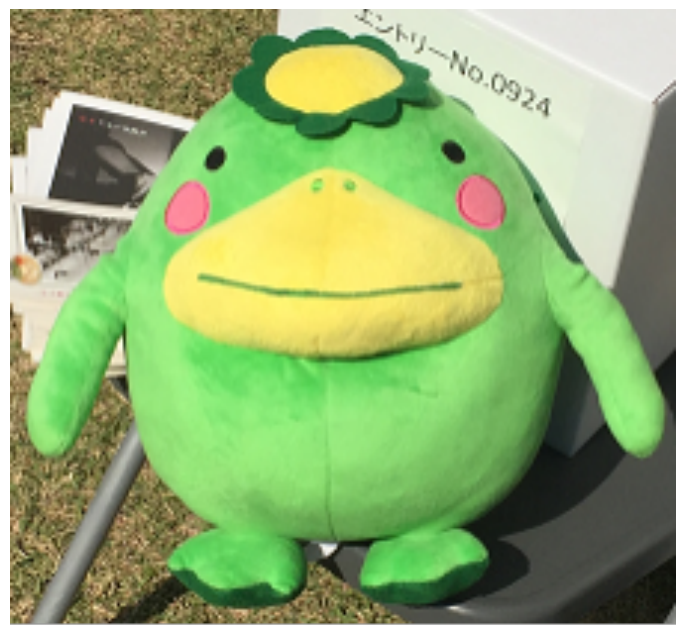

Figure 12: Kuruppa: yuru kyara for Kurume city, Fukuoka prefecture. Photo taken by the author.

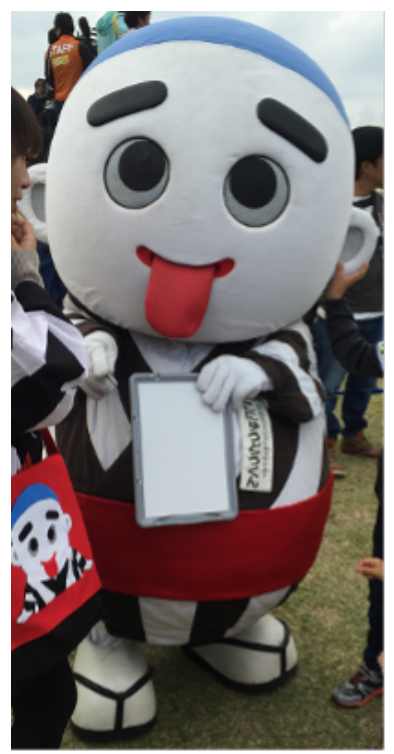

Figure 13: Konyoudoukun: yuru kyara for Yokkaichi town, Mie Prefecture. Photo taken by the author.

\footnotetext{
${ }^{20}$ Kappa are mythical Japanese aquatic creatures that reside in rivers and streams. They are generally considered to be green in colour with scaly and slippery skin. Their power and strength lie in the indented dish-like formation on their heads, which needs to be always kept filled with water. If treated right, they help in irrigation by providing ample water, and if they are mistreated, they bring about floods and draught. Hence in many agricultural villages they are called water deities or suijin 水神 (Foster 2015: 157-158).

${ }^{21}$ Akaname (filth lickers) are small Japanese supernatural creatures that are believed to reside in filthy bathhouses, mucky toilets, and deserted houses. They have naked bodies, greasy hair, and come in varied colours. They have a long, viscid tongue with which they lick all the dirt and grime (Yoda and Alt 2013: 200).
} 
In Japanese religious history, the $y \bar{o} k a i$ is often called a kami. The kami is not always a good and benevolent spirit; it can also be fierce and distinctive. In fact, there are two attributes to a kami. One is aratama 荒魂 (rough and fierce) and the other is nigitama 和魂 (gentle and benevolent). The aratama can be oni 鬼, which falls under the category of yokkai (Foster 2015: 20). According to renowned folklorist Yanagita Kunio (2008), the line between the kami being good and yōkai being bad is extremely blurry and often depends on one's perception. According to Komatsu Kazuhiko 小松 和彦, the kami are "worshipped yōkai" and the yōkai are "unworshipped kami" (Foster 2015: 21). This indicates how the concepts of yōkai and kami are essentially related, bringing in more religious elements into the yuru kyara that are designed for based on the concept of yōkai.

Two more yuru kyara found in the Yuru Kyara Grand Prix 2016, whose designs were not based on an engimono or yōkai but nevertheless used religious motifs in their design, are Shimanekko しまねつこ from Shimane prefecture and Kamirin from Kamijima town, Ochi 越智郡 district, in Ehime prefecture.

Shimanekko has the roof of the popular shrine Izumo Taisha 出雲大社 as its hat and a shimenawa as a scarf around its neck. It is an extremely popular yuru kyara and tourism in Izumo city 出雲市 has increased exponentially since the creation of Shimanekko. Izumo Taisha is deemed a powerful shrine, with the mythical creator of the land of Japan Okuninushi no Okami 大已貴神 being enshrined in it. Although it is supposed to be a powerful and sacred entity, the use of the shrine roof as a motif for the design of the city mascot was not a problematic or contested idea. Although not officially adopted by the shrine, the mascot in fact helps to extensively promote the shrine increasing its visitors and followers. Shimanekko is one of the more popular yuru kyara in Japan. The YouTube video "Shimanekko Song and Dance" (Shimanekko uta \& dansu しまねつこのうた\&ダンス), uploaded in August 2011, has over 630,000 views as of May 2021. The comments on YouTube are mostly positive and full of adoration for Shimanekko. The lyrics of the song describe it as a Maneki Neko 招き猫 (beckoning cat) welcoming people to Shimane prefecture. The video's high number of views and likes suggest that Shimanekko is well-received by the people, and its efforts to increase tourism in Shimane and Izumo Taisha shrine is being successful (Sanborn 2013). With its various religious motifs in its design-like a shimenawa for the scarf and the roof of Izumo Taisha for its hat-Shimanekko shows how the yuru kyara use these religious imageries and symbols in their designs. 
The yuru kyara Kamirin かみりん from Kamijima 上島町, Ehime prefecture, which looks like a cute hedgehog-like creature, has an extensive narrative behind it. It describes Kamirin's character as being moody and whimsical and mentions what Kamirin finds enjoyable, such as going to the beach in the early afternoon, eating fish from Kamijima, and so on. Soon after that, Kamirin is designated as a kami that lives in seas and protects its people. Whenever fishermen and anglers meet the kami, they always get a good catch. ${ }^{22}$

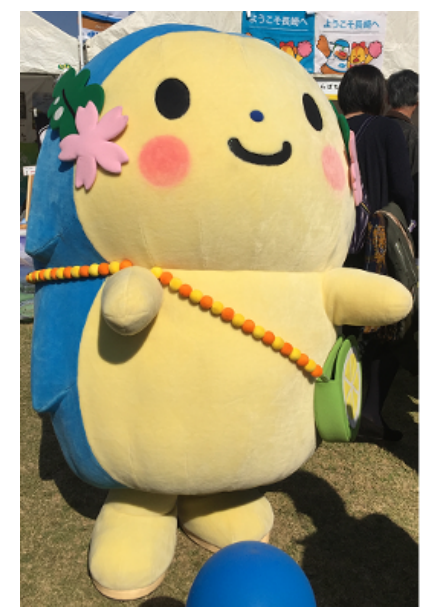

Figure 14: Kamirin: yuru kyara for Kamijima town, Ehime prefecture. Photo taken by the author.

This shows the blurry lines between a secular commercial character (yuru kyara) used for the promotion of a town, city, or prefecture, and its designation as a kami to be revered and possessed for good luck. This amalgamation of religious motifs into the production of popular cultural elements like yuru kyara yet again indicates how a seemingly secular popular culture entity called yuru kyara can have significant religious undertones.

In the Yuru Kyara Grand Prix 2016 a survey was conducted in which one hundred questionnaires were given to the people visiting the event. Ninety-five out of the one hundred questionnaires were fully and correctly filled out. Some of the questions from the questionnaire will be analysed below.

One of the questions was "Do you think kyara have a spirit or soul in them?" (あ) なたはキャラクター/ゆるキャラに魂があると思いますか). Out of the people who filled out the questionnaire, sixty-six per cent gave a positive response, which suggests that the idea of anything possessing a soul or spirit is quite dominant in some circles at least. Japanese religion is characterised by an ideology that all things, even human

\footnotetext{
22 Information from the pamphlet in the Kamirin kiosk in Yuru Kyara Grand Prix 2016, Matsuyama, Ehime prefecture.
} 
made objects, potentially possess a spirit (Kalland 1997) — an idea that is well encapsulated by the concept of tsukumogami つくも神.

Tsukumogami are animate household objects or tool spectres. They are mentioned in an otogizōshi お伽草子 (companion tale) entitled Tsukumogami ki 付喪神記 (Record of Tool Spectres) of the Muromachi Period (1333-1573). According to the tale, after about one hundred years of service, the household objects like tools, containers, and others receive a soul. Like all objects with souls, they then develop independent spirits. These household objects get extremely offended whenever they are being disposed by their human owners, whom they have so loyally served for a long span of time, which in turn makes them transform into vengeful spirits. However, with the teachings of Shingon Buddhism, these spirits let go of their evil ways and devote their lives to religious service (Reider 2009). Tsukumogami are typically categorised as yōkai and as kami of an evil sort that can be appeased by worship (Komatsu 1999). There are several scrolls depicting these tool spectres and their stories, called tsukumogami emaki 付袁神絵巻. These scrolls contain stories about the origins of the tsukumogami, their malicious acts, and finally their enlightenment. They can be found at Sōfuku-ji 崇福寺 in Gifu city 岐阜市 in central Japan, National Diet Library, and the Tōkyō National Museum (Occhi 2012).

The concept of tsukumogami is not merely related to a fabled tale of the past, but some traces for the concern for old tools and other possessions can still be found in contemporary Japan — especially in the religious ritual of kuyo 供養 (mortuary rites) for inanimate objects. The kuyo rites are carried out for diverse items, such as needles, dolls, chopsticks, combs, eyeglasses, clocks, scissors, personal seals (hanko はんこ), knives, and semiconductors. These mortuary rituals are generally performed by people who have special connection to the object for which the rite is performed. For example, hari kuyo 針供養 (memorial for needles) are generally done by sewing schools or seamstresses. Such rites are performed by Buddhist and Shinto priests, generally as a thanksgiving to the tools that have benefitted the user. Hari kuyo and ningyo kuyo 人形供養 (memorial for dolls) are quite popular and widespread. Awashima Kada 淡島加太 shrine in Wakayama 和歌山県 is very popular for ningyo kuyo and receives more than 300,000 dolls per year. Hari kuyo is performed throughout Japan, and these rituals can be also witnessed in Tōkyō's Sensoji (Kretschmer 2000).

The above analysis shows that there is a strong belief in Japanese society that inanimate objects possess spirits. Hence, the kind of response received from the questionnaire, in which it is believed that a kyara has a spirit, elevates the kyara's position from a mere product for promotion and advertising to something that has an organic entity, which can be perceived by its consumers in many different ways, including as an entity that can be possessed for good fortune like an engimono, or something that can be revered and even deified to an extent. The other questions highlight this observation further: "If a kyara shrine was constructed, would you visit it?" and "If you visit that shrine would you pray or wish for something?" Sixty-six per cent of the 
responses to both questions were positive. This solidifies the position as to how much the so-called secular kyara from the popular culture realm crosses towards the more sacred realm of religion.

\section{Conclusion}

The introduction of mascot characters in religious spaces cannot be viewed only as a gimmick to attract visitors. They hold a significant meaning for the people and are a vital part of the whole experience of temple/shrine visits. According to scholars like Aihara Hiroyuki 相原博之 (2007), Aoki Sadashige 青木貞茂 (2014), and Inuyama Akihiko 犬山秋彦 and Sugimoto Masamitsu 杉元政光 (2012), the consumption of these mascot characters (or kyara) brings about a sense of calmness, sanctuary, and even healing. In her research, Mary Birkett (2012) mentioned that mascots can attract and appeal to people of all generations and age groups. With the ubiquitous presence of mascots in Japan and a thriving industry around them, the question remains as to why people purchase them. Lissa Barrows (2014) argues that the popularity of these mascots is due to Japan's animistic and polytheistic history that has millions of deities. In Barrow's interview with the character expert Miura Jun, who coined the term yuru kyara, Miura said that Japan's fascination with characters is largely linked to its history.

Yuko Minowa (2014) investigates the cultural reasons behind the consumption and marketing of anthropomorphised characters (or kyara) in Japan. According to her findings, it is the healing, liberating, and empowering effects of the anthropomorphised characters - which are almost like a spiritual movement - that enables their consumption and massive usage in marketing. In a postmodern, consumerist Japanese society, the kyara can be a new manifestation of older kami, yōkai, and engimono that people consume for good luck and well-being.

Thus, the reason behind the introduction of kyara in religious spaces is intrinsically linked to the fusion of play, entertainment, and religion in Japanese religiosity, and the impact it has on religious spaces is that of a certain kind of renovation of Japanese religiosity. In other words, it can be argued that the long existing tradition of Japanese religion combines the secular elements of play and entertainment with the sacred elements of religion and diminishes the contrast between the two. This shows that such a conflation is not just a desperate measure taken by religious spaces because of the constraints of a contemporary society imposed by the forces of consumerism and secularisation, but also a continuation of a tradition - especially from the Edo era - in a regularly renovating fashion. The impact that it has on religion in those spaces is one of recreation and reinvention, leading to shūkyō asobi. Religion in these spaces is 
transformed and practiced in a diversified and renewed way, thus opposing the secularisation theory that suggests the dwindling and diminishing role of religion in contemporary society.

\section{REFERENCES}

Aihara, Hiroyuki 相原博之. 2007. Kyara-Ka suru Nippon キャラ化するニッポン [Japan Turning into Character]. Tōkyō 東京: Kōdansha 講談社.

Aoki, Sadashige 青木貞茂. 2014. Kyarakutā pawā: yurukyara kara kokka burandingu made キャ ラクターパワゆるキャラから国家ブランディングまで [Character Power: From Yuru Kyara to National Branding]. Tōkyō 東京: NHK エヌエイチケイ.

Asakura Kamezô 朝倉亀三. 1977. Misemono kenkyû 見世物研究 [Research of Show Exhibits]. Kyōto 京都: Shimonkaku Shuppan 思文閣出版.

Azuma, Hiroki. 2009. Otaku: Japan's Database Animals. Minneapolis: University of Minnesota Press.

Barrows, Lissa. 2014. "Planning with Character: Gotouchi Kyara and Place Branding in Japan." M.A. thesis, Columbia University, USA.

Belson, Ken and Brian Bremner. 2003. Hello Kitty: The Remarkable Story of Sanrio and the Billion Dollar Feline Phenomenon. Singapore: John Wiley \& Sons.

Birkett, Mary. 2012. “Amateur Mascots on the Loose: The Pragmatics of Kawaii (Cute).” Ph.D. thesis, University of Michigan, USA.

Bloom, Paul. 2010. How Pleasure Works: The New Science of Why We Like and What We Like. New York: W. W. Norton.

Cali, Joseph and John Dougill. 2012. Shinto Shrines: A Guide to the Sacred Sites of Japan's Ancient Religion. Honolulu: University of Hawai' $\mathrm{i}$ Press.

Chiba, Reiko. 2012. Seven Lucky Gods of Japan. Tokyo: Tuttle Publishing.

Daniels, Inge Maria. 2003. "Scooping, Raking, Beckoning Luck: Luck, Agency and the Interdependence of People and Things in Japan." Journal of the Royal Anthropological Institute, 9 (4), pp. 619-638.

Einstein, Mara. 2008. Brands of Faith: Marketing Religion in a Commercial Age. London and New York: Routledge.

Faure, Bernard. 2011. "From Bodhidharma to Daruma: The Hidden life of a Zen Patriarch." Japan Review, 23, pp. 45-71.

Foster, Michael Dylan. 2015. The Book of Yōkai: Mysterious Creatures of Japanese Folklore. Berkeley: University of California Press.

Galbraith, Patrick W. 2009. "Moe: Exploring Virtual Potential in Post-Millennial Japan.” Electronic Journal of Contemporary Japanese Studies, 9 (3). Online: https://www.japanesestudies.org.uk/articles/2009/Galbraith.html (accessed: June 27, 2021).

Hur, Nam-lin. 2000. Prayer and Play in Late Tokugawa Japan: Asakusa Sensōji and Edo Society. Cambridge, MA: Harvard University Asia Center.

Inuyama, Akihiko 犬山秋彦, and Sugimoto Masamitsu 杉元政光. 2012. Yurukyara-Ron: Yurukunai “yurukyara” no Jittai ゆるキャラ論—ゆるくない「ゆるキャラ」の実態 [The Theory of Yurukyara: The Reality of Non-soft “Yurukyara”]. Tōkyō 東京: Boijā ボイジャー. 
Itō, Gō 伊藤剛. 2005. Tezuka izu Deddo: Hirakareta manga hyōgenron he テッ゙カ・イズ・デッド ひ らかれたマンガ表現論へ [Tezuka is Dead: Towards an Open Theory of Manga Expression]. Tōkyō 東京: NTT Shuppan エヌティティ出版.

Iwabuchi, Koichi. 2008. "Lost in TransNation: Tokyo and the Urban Imaginary in the Era of Globalization.” Inter-Asia Cultural Studies, 9 (4), pp. 543-556.

Kalland, Arne. 1997. "Culture in Japanese Nature Asian Perceptions of Nature: A Critical Approach." In Ole Bruun and Arne Kalland, eds., Asian Perceptions of Nature: A Critical Approach. Surrey: Curzon Press, pp. 243-257.

Kashio, Naoki 樫尾直樹. 2010. Supirichuariti kakumei: Gendai reisei bunka to hirakareta shūkyō no kanōsei スピリチュアリテイ革命: 現代霊性文化と開かれた宗教の可能 [Spirituality Revolution: Contemporary Spiritual Culture and the Possibility of Open Religion]. Tōkyō 東京: Shunjusha 春秋社.

Komatsu, Kazuhiko. 1999. "Supernatural Apparitions and Domestic Life in Japan." The Japan Foundation Newsletter, 27 (1), pp. 5-20.

Kretschmer, Angelika. 2000. "Mortuary Rites for Inanimate Objects: The Case of Hari Kuyō." Japanese Journal of Religious Studies, 27 (3/4), pp. 379-404.

Kuresawa, Takemi 暮沢剛巳. 2010. Kyarakutā Bunka Nyûmon キャラクター文化入門[Character Culture Introduction]. Tōkyō 東京: NTT Shuppan エヌティティ出版.

MacWilliams, Mark W. 2014. Japanese Visual Culture: Explorations in the World of Manga and Anime. London: Routledge.

Masato, Mori 森正人. 2005. Shikoku Henro no Kingendai: Modan Henro Kara Iyashi no Tabi Made 四国遍路の近現代:「モダン遍路」から「癒しの旅」まで [Modern Shikoku Pilgrimage: From Modern Pilgrimage to Healing Journey]. Ōsaka 大阪: Sōgensha 創元社.

McGray, Douglas. 2002. “Japan's Gross National Cool.” Foreign Policy, 130, pp. 44-54.

McVeigh, Brian J. 2000. "How Hello Kitty Commodifies the Cute, Cool and Camp: 'Consumutopia' Versus 'Control' in Japan.” Journal of Material Culture, 130, pp. 225-245.

Miura, Jun みうらじゅん.2009. Zen Nihon Yuru Kyara Kōshiki Gaidobukku 全日本ゆるキャラ公式 ガイドブック [All Japan Wobbly Character Official Guidebook]. Tōkyō 東京: Fusōsha 扶桑社.

Minowa, Yuko. 2014. "Feline Fetish and Marketplace Animism." In Stephen Brown and Sharon Ponsonby-McCabe, eds., Brand Mascots: And Other Marketing Animals. London: Routledge, pp. 91-109.

Miyake, Hitoshi. 2001. Shugendo: Essays on the Structure of Japanese Folk Religion. Edited by H. Byron Earhart. Ann Arbor: Center for Japanese Studies, University of Michigan.

Moriarty, Elizabeth. 1972. "The Communitarian Aspect of Shinto Matsuri." Asian Folklore Studies, 31 (2), pp. 91-140.

Nelson, John K. 2012. "Japanese Secularities and the Decline of Temple Buddhism.” Journal of Religion in Japan, 1 (1), pp. 37-60.

Occhi, Debra J. 2012. "Wobbly Aesthetics, Performance, and Message: Comparing Japanese Kyara with their Anthropomorphic Forebears." Asian Ethnology, 71 (1), pp.110-127.

Okamoto, Takeshi. 2015. "Otaku Tourism and the Anime Pilgrimage Phenomenon in Japan." Japan forum, 27 (1), pp. 12-36.

Plutschow, Herbert. 2013. Matsuri: The Festivals of Japan: With a Selection from PG O'Neill's Photographic Archive of Matsuri. London: Routledge.

Porcu, Elisabetta. 2013. "Sacred Spaces Reloaded: New Trends in Shinto.” In Matthias Middell, ed., Self-Reflexive Area Studies. Leipzig: Leipziger Universitätsverlag, pp. 279-294.

Porcu, Elisabetta. 2014. "Pop Religion in Japan: Buddhist Temples, Icons, and Branding." The Journal of Religion and Popular Culture, 26 (2), pp. 157-172. 
Possamai, Adam. 2005. Religion and Popular Culture: A Hyper-Real Testament. Brussels: Peter Lang.

Reader, Ian. 2007. "Pilgrimage Growth in the Modern World: Meanings and Implications." Religion, 37 (3), pp. 210-229.

Reader, Ian and George Joji Tanabe. 1998. Practically Religious: Worldly Benefits and the Common Religion of Japan. Honolulu: University of Hawai'i Press.

Reider, Noriko T. 2009. "Animating objects: Tsukumogami ki and the Medieval Illustration of Shingon Truth.” Japanese Journal of Religious Studies, 36 (2), pp. 231-257.

Rusu, Renata Maria. 2012. "The Sakaki Tree-From Myth to Modern Japan.” Cogito, 4. Online: https://cogito.ucdc.ro/2012/vol4n2/ro/8 the-sakaki.pdf (accessed: June 27, 2021).

Sanborn, Agliano A. 2013. "Country of Lore, Country of Legend: Reimagining Rural Tourism in the Digital Age. A Case Study of Shimane Prefecture.” M.A. Thesis, Harvard University, USA.

Schreiber, Mark. 2000. "Jidaigeki: TV Heroes Face a New Century.” Japan Quarterly, 47 (4), pp. $58-66$.

Shimazono, Susumu. 2004. From Salvation to Spirituality: Popular Religious Movements in Modern Japan. Melbourne: Trans Pacific Press.

Shimazono, Susumu. 2012. "From Salvation to Spirituality: The Contemporary Transformation of Religions Viewed from East Asia.” Religious Studies in Japan, 1, pp. 3-23.

Stevens, Carolyn S. 2014. "Cute but Relaxed: Ten Years of Rilakkuma in Precarious Japan.” A Journal of Media and Culture, 17 (2), pp. 1-10.

Sutera, Jillian Rae. 2016. "Who Is Hikonyan? The Phenomenon of Japanese Yuru-Chara." Sociology, 6 (12), pp. 775-782.

Thomas, Jolyon Baraka. 2008. "Religious Manga Culture: The Conflation of Religion and Entertainment in Contemporary Japan.” M.A. Thesis, University of Hawai'i, USA.

Thomas, Jolyon Baraka. 2012. Drawing on Tradition: Manga, Anime, and Religion in Contemporary Japan. Honolulu: University of Hawai'i Press.

Thomas, Jolyon Baraka. 2015. "The Buddhist Virtues of Raging Lust and Crass Materialism in Contemporary Japan.” Material Religion, 11 (4), pp. 485-506.

Yanagita, Kunio. 2008. The Legends of Tono: 100th Anniversary Edition. Translated by Ronald A. Morse. Lanham: Lexington Books.

Yoda, Hiroko and Matt Alt. 2013. Yōkai Attack! The Japanese Monster Survival Guide. North Clarendon: Tuttle Publishing. 